\title{
Drivers of amphibian declines: effects of ultraviolet radiation and interactions with other environmental factors
}

\author{
Lesley A. Alton ${ }^{1,2^{*}}$ and Craig E. Franklin ${ }^{1}$
}

\begin{abstract}
As a consequence of anthropogenic environmental change, the world is facing a possible sixth mass extinction event. The severity of this biodiversity crisis is exemplified by the rapid collapse of hundreds of amphibian populations around the world. Amphibian declines are associated with a range of factors including habitat loss/ modification, human utilisation, exotic/invasive species, environmental acidification and contamination, infectious disease, climate change, and increased ultraviolet-B radiation (UVBR) due to stratospheric ozone depletion. However, it is recognised that these factors rarely act in isolation and that amphibian declines are likely to be the result of complex interactions between multiple anthropogenic and natural factors. Here we present a synthesis of the effects of ultraviolet radiation (UVR) in isolation and in combination with a range of naturally occurring abiotic (temperature, aquatic $\mathrm{pH}$, and aquatic hypoxia) and biotic (infectious disease, conspecific density, and predation) factors on amphibians. We highlight that examining the effects of UVR in the absence of other ecologically relevant environmental factors can greatly oversimplify and underestimate the effects of UVR on amphibians. We propose that the pathways that give rise to interactive effects between multiple environmental factors are likely to be mediated by the behavioural and physiological responses of amphibians to each of the factors in isolation. A sound understanding of these pathways can therefore be gained from the continued use of multi-factorial experimental studies in both the laboratory and the field. Such an understanding will provide the foundation for a strong theoretical framework that will allow researchers to predict the combinations of abiotic and biotic conditions that are likely to influence the persistence of amphibian populations under future environmental change.
\end{abstract}

Keywords: Amphibian declines, Ultraviolet radiation, Temperature, Aquatic pH, Hypoxia, Disease, Chytrid, Density effects, Predation, Interactive effects, Multiple stressors, Extinction

\section{Background}

The current biodiversity crisis is exemplified by the global loss and decline of numerous amphibian species with between 2063 (32\%) and 3630 (56\%) of 6490 extant evaluated species listed as threatened with extinction [1]. By comparison, $22-37 \%$ of mammals and $13-14 \%$ of birds are threatened [1]. Between 1980 and 2006, 470 amphibian species have had their IUCN Red List category changed to one of higher threat indicating that many amphibian declines have been rapid [2]. Curiously, 226

\footnotetext{
* Correspondence: lesley.alton@monash.edu
${ }^{1}$ School of Biological Sciences, The University of Queensland, QLD, Brisbane

* Correspondence: lesley.alton@monash.edu
${ }^{1}$ School of Biological Sciences, The University of Queensland, QLD, Brisbane 4072, Australia

${ }^{2}$ Current address: School of Biological Sciences, Monash University, Melbourne, VIC 3800, Australia
}

(48\%) of these rapidly declining species are disappearing despite the availability of suitable habitat [2]. These socalled "enigmatic" declines have occurred predominantly in stream-side habitats within protected montane areas throughout the Neotropics and Australia [3] (Fig. 1). The global and enigmatic nature of amphibian declines is cause for great concern: not only are amphibians utilised by humans for various purposes, they also constitute a significant proportion of the total vertebrate biomass [4] and are an integral component of trophic dynamics and energy flow within ecosystems [5]. Understanding why amphibians are declining is therefore critical, not only for their own preservation, but also for the preservation of other species. 


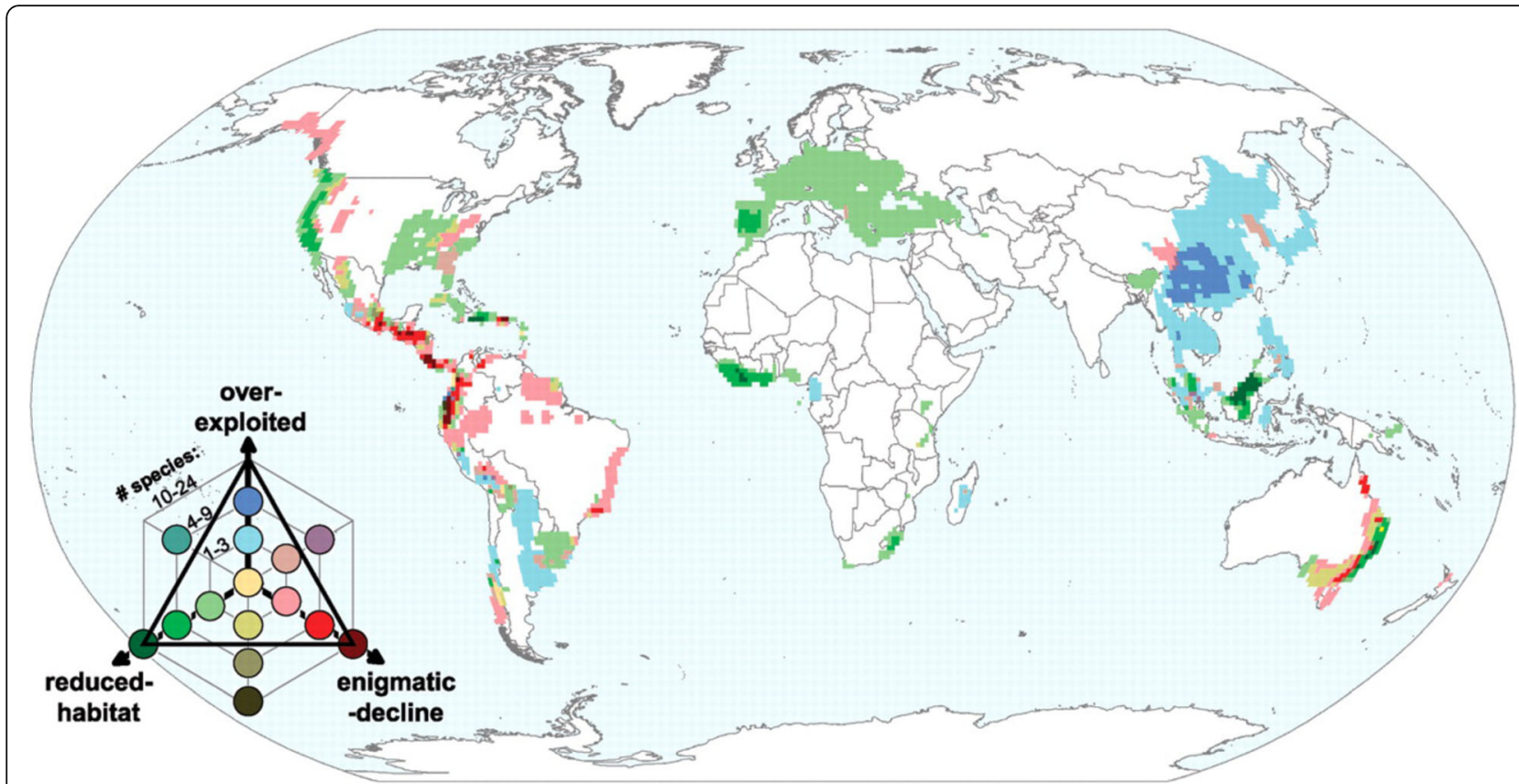

Fig. 1 The geographical distribution of "rapidly declining" amphibian species based on the primary cause of their decline: significant habitat loss ("reduced habitat", shades of green); heavy extraction by humans ("over exploited", shades of blue); and unknown processes where suitable habitat remains ("enigmatic decline", shades of red). Intermediate colours are shown in cases where equal numbers of species are experiencing two types of decline in the same cell, as shown in the key. Darker colours correspond to larger numbers of rapidly declining species. From Stuart et al. [3]. Reprinted with permission from AAAS

No simple explanation currently accounts for the global loss and decline of amphibian populations, but several causes have been implicated, including: habitat loss/ modification; human utilisation; exotic/invasive species; environmental acidification from acid precipitation; environmental contamination from fertilisers, pesticides and other pollutants; infectious disease; anthropogenic climate change; and increased ultraviolet- $B$ radiation (UVBR) due to anthropogenic ozone depletion [6]. Habitat loss/modification is considered to be one of the largest threats to amphibian populations, affecting $63 \%$ of all amphibian species and $87 \%$ of all threatened amphibian species [2]. The mysterious disappearance of amphibians from seemingly pristine habitats, however, alludes to more subtle environmental changes contributing to the amphibian decline phenomenon. Although the infectious disease chytridiomycosis (caused by the pathogenic chytrid fungus Batrachochytrium dendrobatidis, Bd) has been implicated as the proximate cause of most enigmatic declines [6], the involvement of other environmental factors is far from precluded.

With growing awareness of the complexity of natural systems, it has become generally accepted that amphibian declines are unlikely to be a consequence of a single factor, but rather a result of complex interactions between multiple factors [7]. One potential scenario for the cause of declines is that anthropogenic environmental change at global (e.g. climate change, or increased UVBR), regional (e.g. environmental acidification, or contamination) and local scales (e.g. habitat loss/modification) may be interacting with changes in local biotic interactions (e.g. exotic/invasive species, or infectious disease) [8]. What is less often considered is that anthropogenic environmental change at global, regional and local scales is also likely to be interacting with abiotic and biotic factors that occur naturally within amphibian environments. For instance, amphibians must cope with natural variations in temperature and aquatic oxygen while also defending against pathogens, competing with others for resources, and avoiding predation, all of which can be detrimental to their health and survival. Importantly, such natural challenges are present in the pristine habitats where amphibians are declining mysteriously. With amphibian declines recognised as a global phenomenon, and given the perplexing nature of enigmatic declines, understanding the interaction between global-scale environmental change and variability in naturally occurring factors is particularly important.

In this review we focus on the global-scale environmental change of increased environmental UVBR associated with stratospheric ozone depletion, and its potential interactions with a range of naturally occurring abiotic and biotic factors (Fig. 2). Increased UVBR as a potential contributor to amphibian declines has attracted 


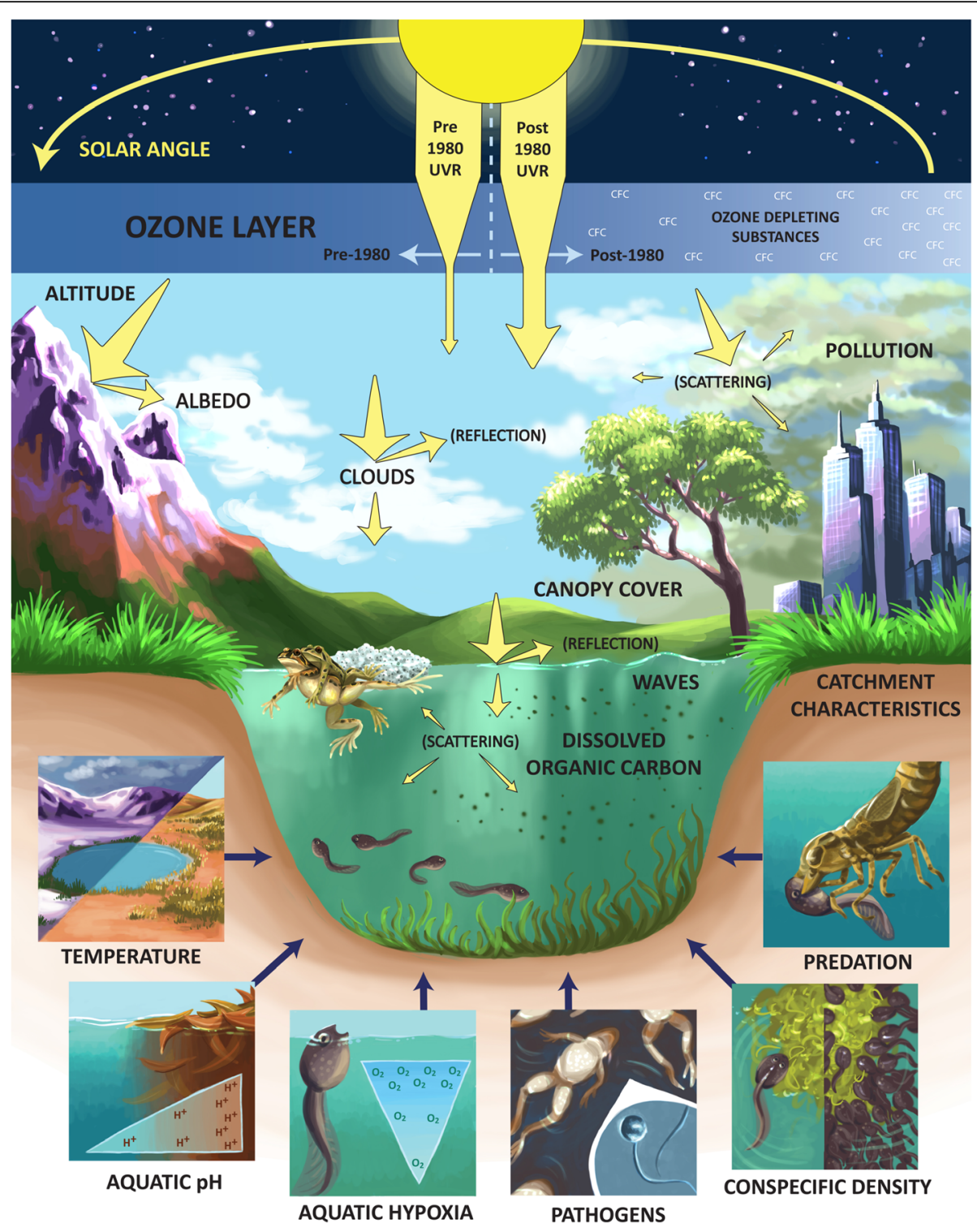

Fig. 2 A summary of the factors that affect transmission of UVR in terrestrial and aquatic environments (see the section "Ultraviolet radiation" for details). In aquatic environments where amphibians reproduce and develop, UVR has the potential to interact with a range of environmental factors including temperature, aquatic $\mathrm{pH}$, aquatic hypoxia, pathogens (such as the chytrid fungus), conspecific density and predation (see the section "Interactive effects of UVR with other environmental factors" for details). Figure drawn by Elia Pirtle. Adapted from Fig. 2.1 and 2.3 in Xenopoulos and Schindler [10]

considerable attention due to the contemporaneous onset of stratospheric ozone depletion and rapid amphibian declines in the late 1970s and early 1980s [3, 9]. In particular, rapid enigmatic declines occurring within pristine stream habitats at high elevations may be associated with increased UVBR. This is because, at these sites, the atmosphere is thinner and has lower levels of pollution resulting in higher UVBR incidence due to less scattering and absorption [10] (Fig. 2). Also, UVBR attenuation in lakes and streams at high elevations is generally low due to low levels of surrounding vegetation and dissolved organic carbon [10] (Fig. 2).
While it is very difficult to definitively attribute amphibian declines to increased UVBR since it is impossible to assess the harm caused to populations that have already declined or no longer exist [11], research beginning in the early 1990s has shown that, on its own, exposure to ultraviolet radiation (UVR) has profound negative effects on several amphibian species. We begin our review with a general introduction to UVR, the factors that influence UVR transmission in the environment, and the implications of increased environmental UVR for living organisms. We then synthesise what is known of the effects of UVR on amphibians and how 
amphibians defend against UVR damage while highlighting gaps in our current knowledge. We follow this section with a review of the interactive effects of UVR combined with the naturally occurring factors of temperature, aquatic $\mathrm{pH}$, aquatic hypoxia, infectious disease, conspecific density and predation, and discuss the potential pathways by which these interactive effects arise. With this review we highlight that examining the effects of UVR in the absence of other ecologically relevant natural factors can greatly oversimplify and underestimate the actions of UVR in natural systems. Finally, we conclude with our thoughts for future directions and considerations.

\section{Ultraviolet radiation}

UVR is the region within the electromagnetic spectrum between the wavelengths of 100 and $400 \mathrm{~nm}$. The wavelengths that are of interest to photobiology are within the ultraviolet-B (UVBR, $280-315 \mathrm{~nm}$ or $280-320 \mathrm{~nm}$ ) and ultraviolet-A (UVAR, 315-400 $\mathrm{nm}$ or $320-400 \mathrm{~nm}$ ) wavebands. This is because as solar radiation passes through the Earth's atmosphere, it is absorbed primarily by stratospheric ozone, which prevents wavelengths shorter than $280 \mathrm{~nm}$ from reaching the surface, but has little effect on wavelengths greater than $340 \mathrm{~nm}$ [12] (Fig. 3). Between these wavelengths there is a steep

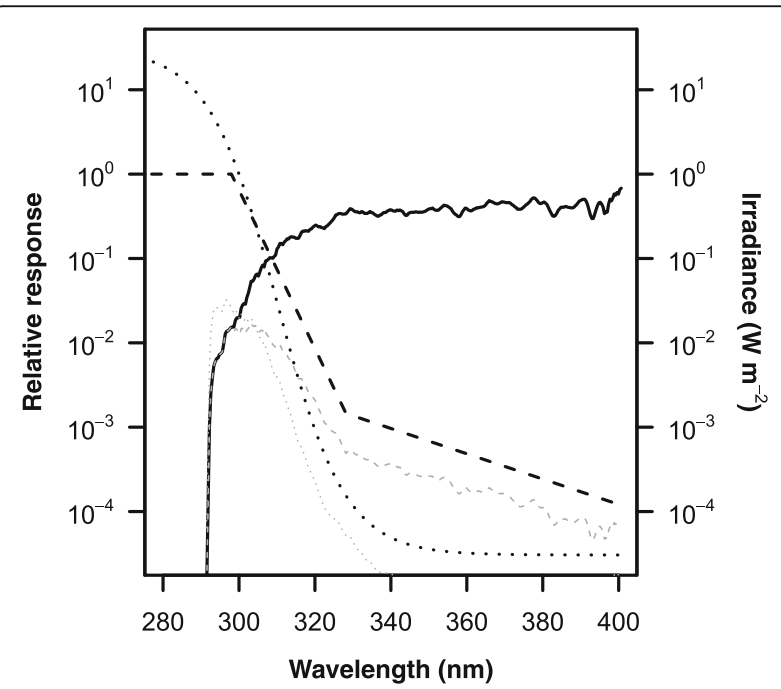

Fig. 3 The black solid line shows the ground-level UV solar irradiance $\left(\mathrm{W} \mathrm{m}^{-2}\right)$ at 11:30 on 11 January 2009 in Brisbane, Australia (a latitude of $27.5^{\circ} \mathrm{S}$ ), on a cloud-free day. The dotted black line shows the action spectrum for DNA damage as determined by Setlow [18] and parameterised by Bernhard et al. [202] (normalised to 1 at $300 \mathrm{~nm}$ ). The dashed black line shows the action spectrum for erythema (sunburn in Caucasian human skin) as proposed by McKinlay and Diffey [19] (normalised to 1 at $298 \mathrm{~nm}$ ). By weighting the solar irradiance with these action spectra, the effective solar irradiance $\left(\mathrm{W} \mathrm{m}^{-2}\right)$ can be determined and is shown by the dotted and dashed grey lines for DNA damage and erythema, respectively reduction in absorption, with the fraction of UVBR that passes through the atmosphere increasing by many orders of magnitude as wavelength increases (Fig. 3). After passing through the stratosphere, the intensity and spectral composition of UVR at ground level varies naturally on a daily and seasonal time scale as a function of both atmospheric and geophysical parameters [10]. Atmospheric transmission of UVR is dependent on absorption by a variety of gases, as well as scattering by air molecules, particulates, and clouds (Fig. 2). The geophysical parameters include Earth-Sun distance, solar elevation, latitude, altitude, and albedo (i.e. reflectivity) (Fig. 2).

\section{Stratospheric ozone depletion}

Following the discovery of the Antarctic ozone 'hole' by Farman et al. [9], it was soon realised that stratospheric ozone depletion was a global phenomenon caused by the build-up of ozone-depleting substances (ODSs), mainly anthropogenic chlorofluorocarbons [13, 14] (Fig. 2). Due to the successful implementation of the Montreal Protocol to phase out ODSs, stratospheric ODS abundances peaked between 1997 and 2000 and have now declined by $10-15 \%$ [14]. The maximum decrease in globally averaged total column ozone was observed in the early 1990s when levels were 5\% below the 1964-1980 average [13] (Fig. 4). Since then, ozone depletion has lessened with the globally averaged total column ozone for 2008-2012 at $2.5 \%$ below the $1964-1980$ average [14] (Fig. 4). However, observed declines in total column ozone vary significantly with latitude (Fig. 4): over the Antarctic $\left(63^{\circ} \mathrm{S}-90^{\circ} \mathrm{S}\right)$, declines in total column ozone of about $40 \%$ occur every October; over the Arctic $\left(63^{\circ} \mathrm{N}-\right.$ $90^{\circ} \mathrm{N}$ ), maximum declines of about $30 \%$ have been observed in March; across the mid-latitudes in the Southern $\left(35^{\circ} \mathrm{S}-60^{\circ} \mathrm{S}\right)$ and Northern $\left(35^{\circ} \mathrm{N}-60^{\circ} \mathrm{N}\right) \mathrm{Hemi}-$ spheres, total column ozone has declined by $6 \%$ and $3.5 \%$, respectively [14]; and in the tropics $\left(20^{\circ} \mathrm{S}-20^{\circ} \mathrm{N}\right)$ where the ozone layer is thinnest and the incidence of UVR is highest, no significant changes in total column ozone have been detected due to substantial natural variability among years [14].

Focus has now turned to stratospheric ozone recovery, which will be slow given the long atmospheric lifetimes of most ODSs [14]. However, anthropogenic greenhouse gas (GHG) emissions substantially influence ozone recovery by causing changes in atmospheric temperature, circulation and chemistry that affect ozone levels both positively and negatively (see [14] for details). Model simulations that account for the effects of ODSs and GHGs on ozone estimate that global total column ozone will return to 1980 levels by the middle of the twentyfirst century, and will eventually exceed 1960 levels [14]. However, in the tropics, total column ozone is projected to be below 1980 levels over the coming decades due to 


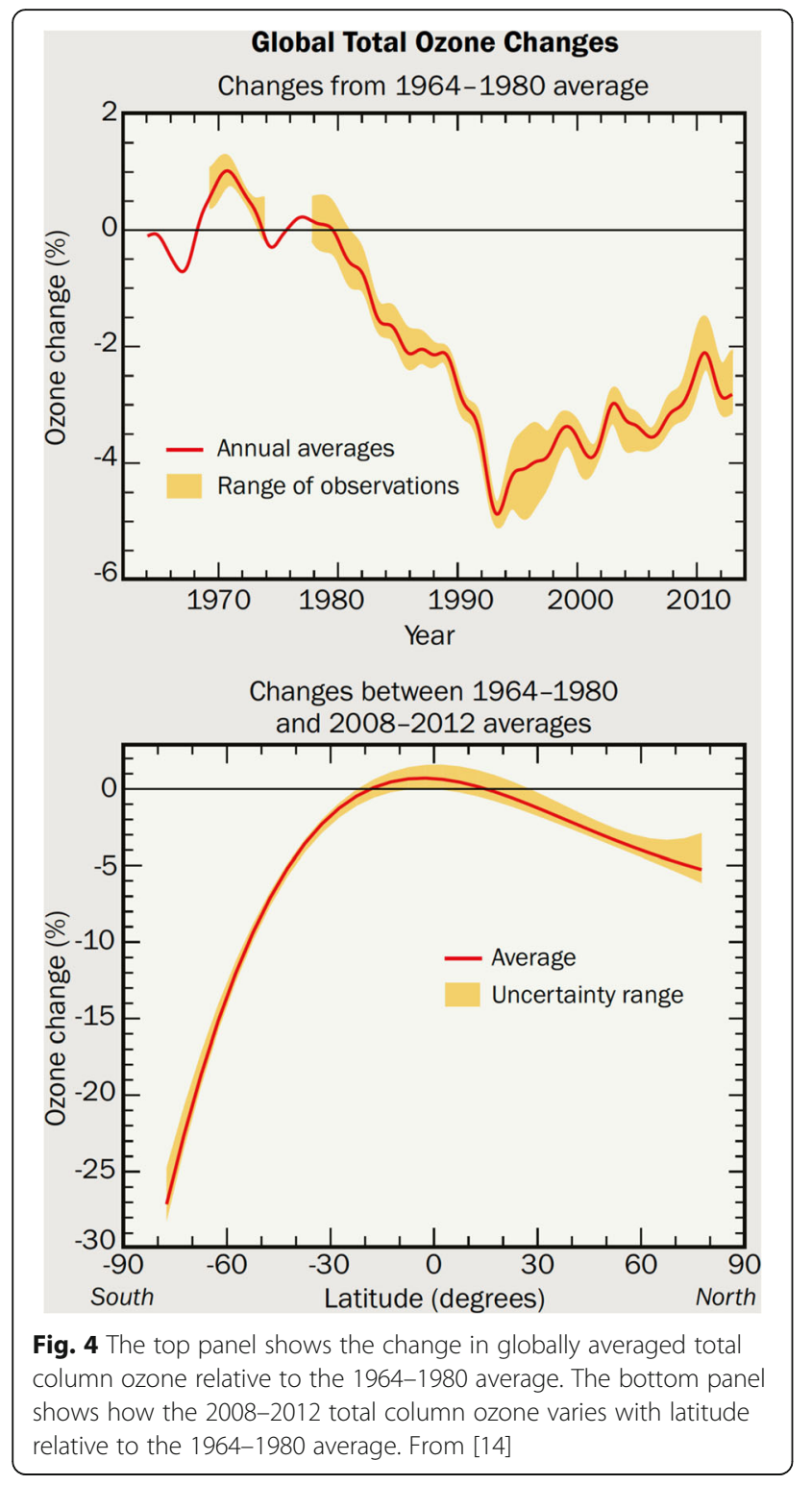

factors associated with GHG-induced climate change [14] (Fig. 5). The implications of the anthropogenic destruction of the ozone layer that began in the late 1970s and early 1980s, and its continued interaction with anthropogenic climate change, will therefore remain a global issue for many decades to come. For amphibians particularly, the predicted continuation of reduced total column ozone over the tropics is cause for concern since amphibian species richness is highest in the tropics [2].

\section{Changes in surface UVR associated with stratospheric ozone depletion}

Since the discovery of the ozone hole over the Antarctic, there has been much concern over the associated increases in UVR at the surface of the Earth. Quantifying the changes in surface UVR associated with stratospheric ozone depletion has been made difficult due to the lack of a long-term, quality-controlled global UVR monitoring system [13]. It has been further complicated by climate change (i.e. changes in cloud cover/ surface albedo) and pollution (e.g. aerosols), which can be more important than ozone in determining the amount of UVR that reaches the surface of the Earth [13] (Fig. 2). Despite these issues, increases in surface UVR have been detected in various locations around the world, though there is substantial variability among sites $[13,15]$. In a comprehensive analysis of satellite data from 1979 to 2008, Herman [16] determined that surface UVR (280-325 nm) has increased significantly at all latitudes $\left(55^{\circ} \mathrm{S}-55^{\circ} \mathrm{N}\right)$ except the equatorial zone (Fig. $6 \mathrm{~A}$ ). However, significant increases in UVBR have been detected at equatorial sites in Central America $\left(8^{\circ} \mathrm{N}-18^{\circ} \mathrm{N}\right)$ that are associated with amphibian declines [17] (Fig. 7). Under clear-sky conditions, increases in erythemal UVR (i.e. sunburning UVR; see below section "Biological effects of UVR on living organisms" and Fig. 3) due to ozone changes range from 5 to $8.5 \%$ in the Southern Hemisphere $\left(30^{\circ} \mathrm{S}-50^{\circ} \mathrm{S}\right)$ and from 3 to $4.4 \%$ in the Northern Hemisphere $\left(30^{\circ} \mathrm{N}-50^{\circ} \mathrm{N}\right)$ [16] (Fig. 6B). However, in the Southern Hemisphere, these increases in erythemal UVR due to ozone depletion have been offset by nearly half due to net increases in the effects of clouds and aerosols, which act to reduce the transmission of UVR through the atmosphere [16] (Fig. 6B). In the Northern Hemisphere, the effects of clouds and aerosols on erythemal UVR increases have generally been negligible [16] (Fig. 6B), but at sites in Europe and Japan, erythemal UVR has continued to increase in recent years due to net reductions in the effects of clouds and aerosols [13].

As with ozone, clear-sky erythemal UVR levels at midlatitudes are projected to return to 1980 levels by the middle of the twenty-first century, but will continue to decrease and be $5-15 \%$ lower than 1980 levels by 2100 [13]. Although evidence of increases in surface UVR in the tropics is limited, the predicted decrease in tropical total column ozone associated with GHG-induced climate change (Fig. 5) is likely to lead to increases in surface UVR [13, 14]. However, these future projections for surface UVR levels do not account for future changes in cloud cover, air pollutants and aerosols. Thus, there is uncertainty surrounding these projections and they must be treated with caution.

\section{Factors that influence the transmission of UVR in aquatic habitats}

While atmospheric and geophysical parameters have a strong influence on the UVR that reaches terrestrial environments, other additional factors are important in determining UVR levels within aquatic environments. The transmission of UVR through water depends on a 


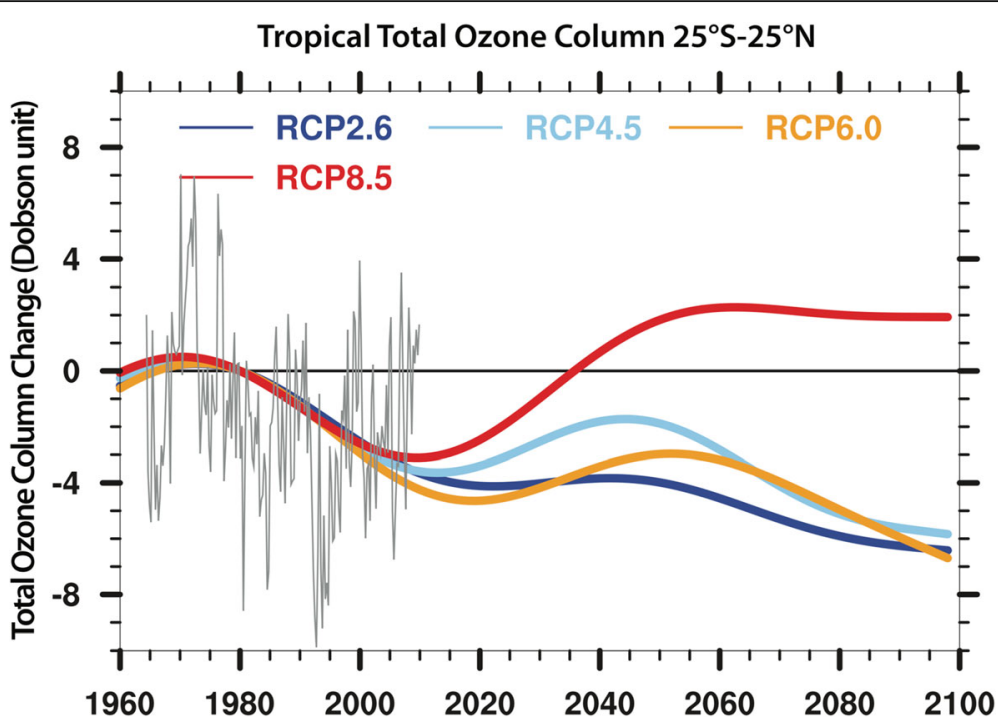

Fig. 5 Model simulations of the changes in total column ozone over the tropics $\left(25^{\circ} \mathrm{S}-25^{\circ} \mathrm{N}\right)$ between 1960 and 2100 relative to the 1980 baseline (coloured lines). Each model follows a different scenario for future greenhouse gas emissions, known as the Representative Concentration Pathways (RCP), and correspond to +2.6 (dark blue), +4.5 (light blue), +6.0 (orange), and $+8.5 \mathrm{~W} \mathrm{~m}^{-2}$ (red) of global radiative forcing (radiative forcing is the difference between the incoming and outgoing energy in the Earth-atmosphere system with increasing positive values indicating an increasing warming effect). Except for RCP 8.5, which specifies large increases in methane, significant decreases in total column ozone over the tropics are projected during the twenty-first century. Also shown are the total column ozone values recorded from ground-based observations relative to the 1964-1978 average (grey line). From [14]

number of parameters at the air-water interface and below the water surface [10] (Fig. 2). The penetration of UVR through the air-water interface depends on the angle and intensity of surface irradiance, water reflectivity and surface waves. Below the water surface, UVR is subject to absorption and scattering by dissolved and particulate matter, of which dissolved organic carbon (DOC) is the most important. Catchment characteristics are important in determining DOC type and concentrations [10]. Typically, wetlands have the highest DOC concentrations, and alpine lakes the lowest. Consequently, UVR transmittance among water bodies can range from centimetres (water with high DOC concentrations) to metres (water with low DOC concentrations). DOC loadings are also influenced by interactions between climate, topography and geology leading to seasonal variations in DOC inputs as a result of differences in precipitation, channel flow rates and lake residence times [10]. In addition to these factors that cause natural variation in the DOC concentrations of aquatic habitats, anthropogenic stratospheric ozone depletion, climate change, and aquatic acidification (caused by anthropogenic emissions of sulphur and nitrogen oxides) can lead to reduced DOC loadings (and consequently increased penetration of UVR underwater) through increased photobleaching, reduced precipitation, and reduced aquatic $\mathrm{pH}$, respectively (explained in detail by [11]). Underwater UVR levels are therefore subject to a wide range of factors that interact with one another in complex ways making it difficult, but particularly important, to understand the impact of increased UVR on aquatic organisms, as well as terrestrial organisms.

\section{Biological effects of UVR on living organisms}

UVR consists of high-energy photons that induce excited states in a variety of molecules, thereby stimulating a range of photochemical reactions that are both detrimental and beneficial to living organisms. While UVR causes injury to cells by damaging DNA, proteins and lipids, it is also necessary for vitamin D synthesis, DNA repair and vision. The biological effects of UVR are dependent on wavelength and are described by action spectra. Two of the most widely accepted reference action spectra are that for DNA damage [18] and erythema (sunburn in Caucasian human skin) [19] (Fig. 3). These action spectra indicate that the most effective wavelengths are below $305 \mathrm{~nm}$ for DNA damage and $328 \mathrm{~nm}$ for erythema, and that a $1 \%$ decrease in total stratospheric ozone can lead to a $2.2 \%$ and $1.1 \%$ increase in effective UVR at the Earth's surface, respectively [20]. Consequently, stratospheric ozone depletion and other factors that influence the amount of UVR that reaches environments have significant implications for living organisms.

\section{UVR effects at the molecular level}

Several molecules within cells absorb UVR, the most important of which are the nucleotide bases within DNA. 

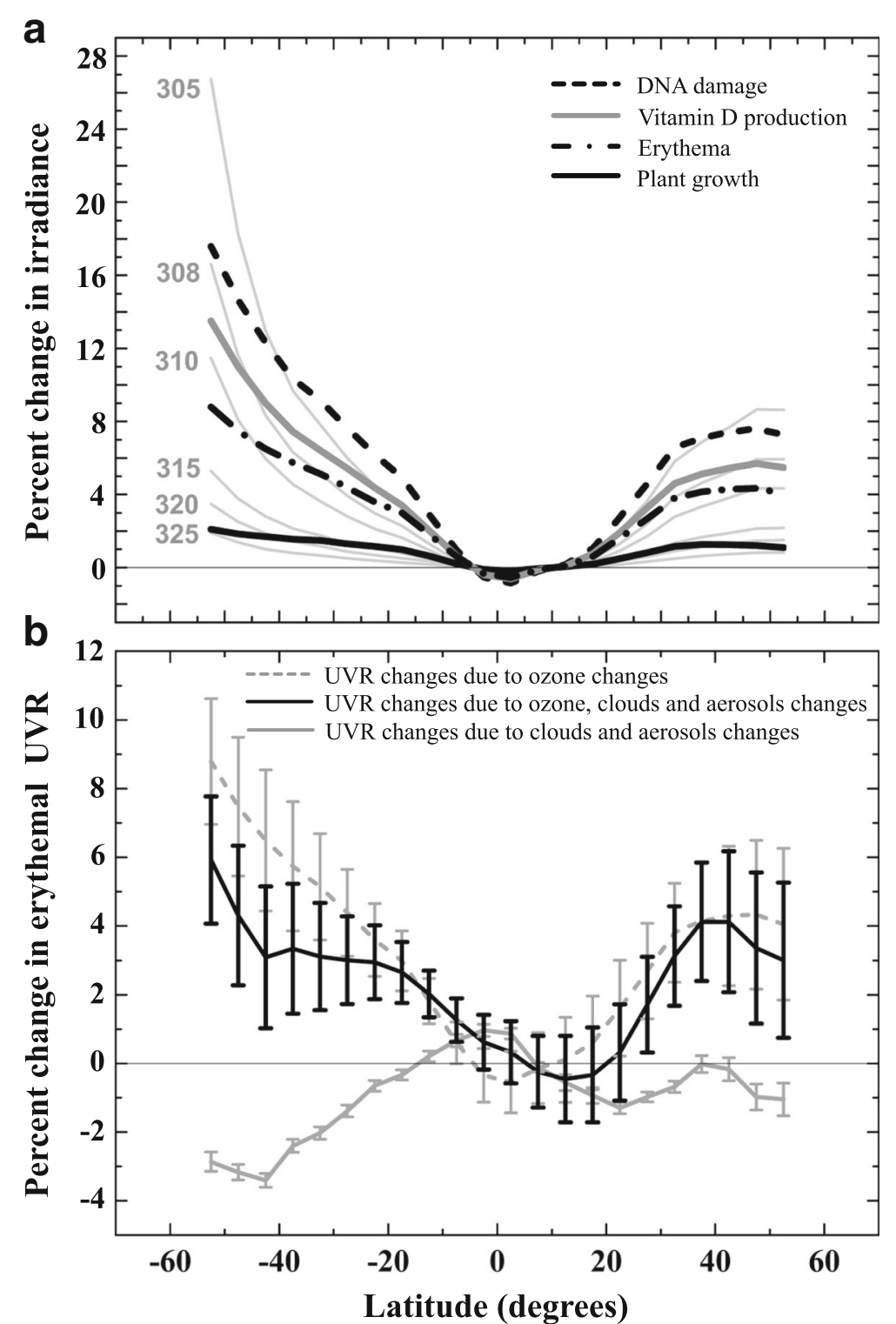

Fig. 6 a The percent change in six monochromatic (305, 308, 310, 315, 320 and 325 nm) UV irradiances (light grey solid lines) as a function of latitude between $55^{\circ} \mathrm{S}$ and $55^{\circ} \mathrm{N}$ (negative latitude values represent the Southern Hemisphere) arising from the total change in ozone amount between 1979 and 2008. Also shown are the changes in UV irradiance weighted with action spectra for DNA damage (black dashed line), vitamin D production (dark grey solid line), erythema (sunburning, black line with dots and dashes), and plant growth (black solid line) (action spectra quantify the relative strength of a biological response at different wavelengths). b The percent change in erythemal UV irradiance between 1979 and 2008 as a function of latitude due to: ozone changes under clear-sky conditions (grey dashed line, equivalent to the black line with dots and dashes in a); changes in clouds and aerosols (grey solid line); and ozone changes combined with changes in clouds and aerosols (black solid line). Adapted from Figs. 11 and 12 in Herman [16]. Reprinted with permission from John Wiley \& Sons, Inc. Copyright 2010 by the American Geophysical Union

When UVR (mainly UVBR) is absorbed by DNA, it causes neighbouring pyrimidine nucleotide bases on the same DNA strand to become linked to form lesions, the most common of which are cyclobutane pyrimidine dimers (CPDs) and (6-4) pyrimidine-pyrimidones (64PPs) [21] (Fig. 8). Absorption of UVR (mainly UVAR) by other molecules, known as photosensitisers, leads to the production of reactive oxygen species (ROS) that react with DNA, proteins and lipids (Fig. 8). Oxidation of DNA by ROS gives rise to several types of lesions, the most common of which is 8-oxo-7,8-dihydroguanine (8oxoGua) [22]. Crosslinks between DNA and proteins also arise from the generation of aldehydes from the oxidation of lipids [23]. The formation of lesions within DNA caused by both direct UVR absorption (e.g. CPDs and 6-4PPs) and UVR-induced ROS (e.g. 8-oxoGua and 


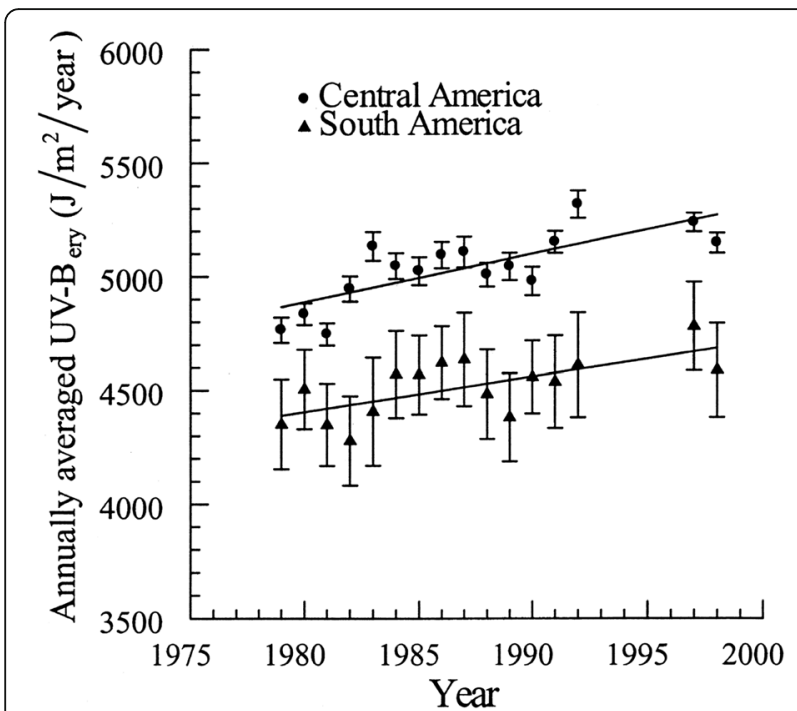

Fig. 7 The change in the annually averaged erythemal (sunburning) ultraviolet-B radiation (UV-B ery, $\mathrm{J} / \mathrm{m}^{2} /$ year) between 1979 and 1998 at sites in Central and South America where amphibian declines have been documented. UV-Bery was significantly greater in Central America compared to South America across all years. UV-Bery increased significantly at sites in Central and South America during the time period, with increases in UV-B $B_{\text {ery }}$ being greater in Central America. Data are annual mean \pm SE. From Middleton et al. [17]. Reprinted with permission from John Wiley \& Sons, Inc.
DNA-protein crosslinks) can result in severe structural distortions in the DNA molecule, as well as cause DNA strand breaks [21]. These DNA lesions and strand breaks can impede DNA transcription and replication, and thus compromise the functional integrity and viability of cells [21]. Oxidation of lipids and proteins by ROS similarly disrupts cellular functioning by disrupting membrane function and causing structural alterations to proteins that lead to a loss of function, modified turnover and altered interactions with other molecules [23, 24]. Depending on the extent of the damage to DNA, protein and lipids, and the capacity for repair (see the section "Defences against UVR damage"), UVR exposure can ultimately lead to mutations and cell death [21] (Fig. 8). Apoptosis (programmed cell death) is an important final defence mechanism that prevents the propagation of cells with mutated genetic material [21] (Fig. 8). However, if a mutation arises in a gene that codes for a protein involved in regulating the cell cycle, differentiation, or apoptosis, then this can lead to tumorigenesis and carcinogenesis [25] (Fig. 8).

\section{Defences against UVR damage}

To protect against UVR-induced molecular damage, organisms have evolved a number of molecular pathways that either prevent UVR damage from occurring, or repair UVR damage once it has occurred (Fig. 8).

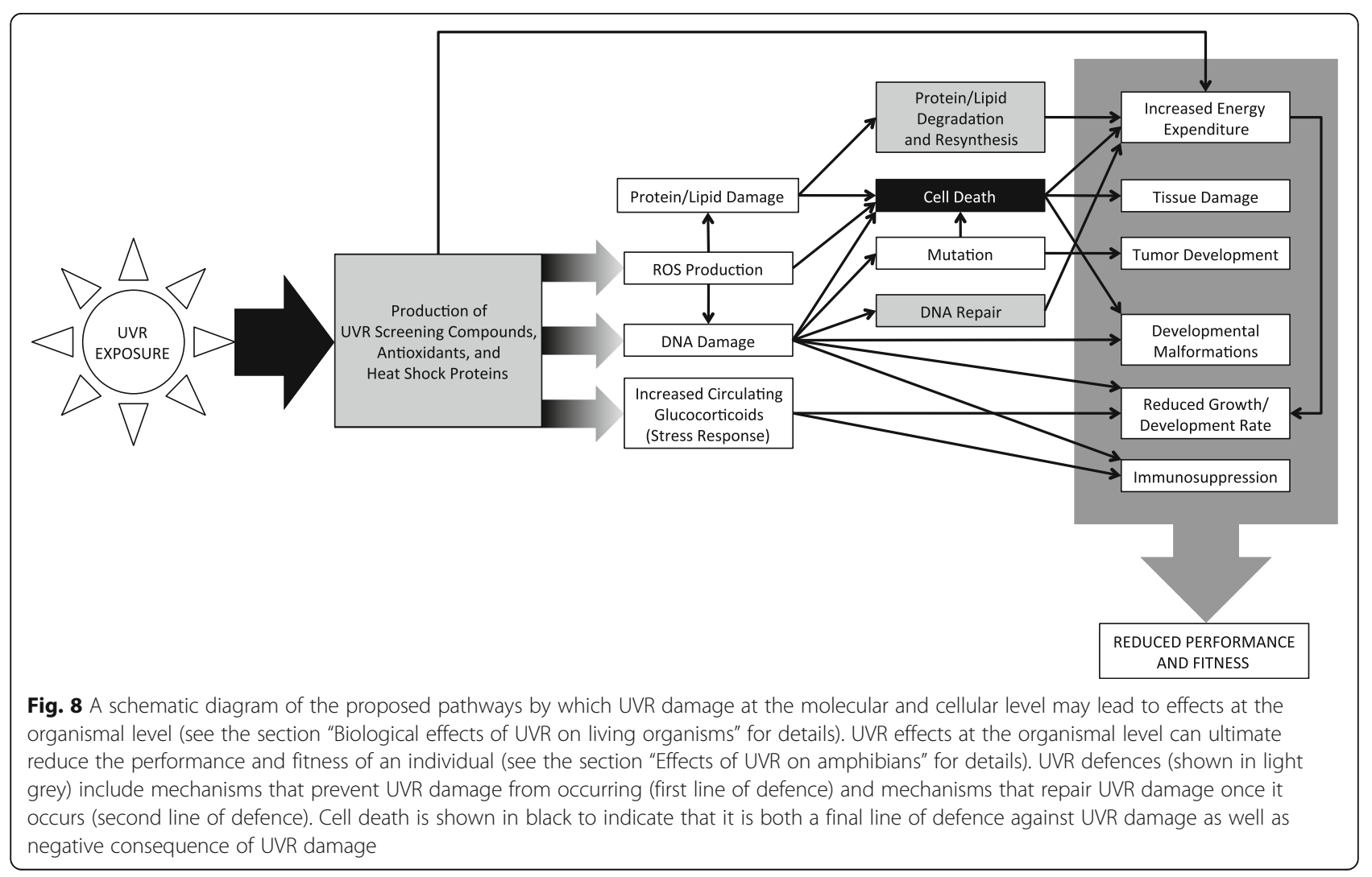


Preventative mechanisms include UVR-screening compounds, antioxidants, and heat shock proteins. UVRscreening compounds are molecules that absorb UVR and are either synthesised by an organism, or absorbed or accumulated through its diet (e.g. mycosporine-like amino acids and melanin) [26]. Antioxidants include non-enzymatic and enzymatic scavengers that remove either oxidant precursors or the oxidants themselves thereby delaying or preventing oxidative damage [24]. Finally, heat shock proteins are molecular chaperones that prevent damage to proteins that can be caused by exposure to environmental stress factors such as UVR [27].

These preventative mechanisms are not completely effective, however, and thus repair mechanisms are a second line of defence against UVR-induced damage (Fig. 8). CPDs and 6-4PPs are able to be repaired by a single-step, error-free reaction known as photoreactivation, in which a photolyase enzyme absorbs a photon of light between 350 and $450 \mathrm{~nm}$ and uses the excitation energy to break the bond between the nucleotide bases, thus returning them to their original state [28]. A more complex process known as excision repair removes and replaces various lesions with newly synthesised DNA [21]. Unlike photoreactivation, excision repair is a multistep process that requires several enzymes and consumes ATP. Although excision repair is a more versatile repair mechanism than photoreactivation, it has the disadvantage of being more kinetically and energetically costly and also more prone to introducing errors into the genetic sequence. It is therefore surprising that while photoreactivation and excision repair are both highly conserved repair mechanisms, placental mammals appear to have lost the ability to repair DNA damage via photoreactivation [21].

Unlike DNA, the majority of UVR-induced ROS damage to proteins does not appear to be repaired. Rather, oxidized proteins are catabolised (i.e. degraded into amino acids), while new replacement proteins are synthesised de novo [24, 29]. There are, however, enzyme systems that can repair damaged proteins [24]. Similarly, oxidised lipids are able to be removed from membranes and resynthesised, but also repaired by certain enzymatic pathways [29].

\section{Consequences of UVR damage}

UVR damage at the molecular and cellular level can result in lethal and sublethal effects at the organismal level, including reduced rates of growth, development and photosynthesis, developmental malformations and abnormalities, tissue damage (sunburn), immunosuppression, and tumor development (Fig. 8). These effects have been reported in many organisms including viruses and bacteria [30], phytoplankton and algae [31], crops and forests [32], crustaceans [33], amphibians [11], fish
[34], and mammals [35]. There are several potential pathways by which UVR damage at the molecular and cellular level gives rise to lethal and sublethal effects at the organismal level (Fig. 8). For instance, UVR-induced DNA damage can cause death and slow the growth and development of an organism by delaying DNA transcription and replication and causing cells to undergo apoptosis [36]. However, slowed growth and other sublethal effects may also arise from the energetic costs associated with UVR defences including the production of screening pigments, DNA repair, the degradation and resynthesis of proteins and lipids, and cell apoptosis [37-40]. UVR exposure can also induce the endocrine stress response by causing an increase in circulating glucocorticoids (e.g. cortisol) ([41], but see [42]), which under chronic conditions can lead to reduced growth and immunosuppression [43]. Immunosuppression can also be triggered by UVR-induced DNA damage, which affects various cell-mediated immune responses including the function of antigen presenting cells and stimulating the production of soluble immunosuppressive mediators [44].

\section{Effects of UVR on amphibians}

With global increases in UVR thought to be contributing to amphibian declines, there has been considerable interest in the effects of UVR on amphibians, predominantly on the early life stages that precede metamorphosis. Being ectotherms, solar radiation is an important source of heat for amphibians, and thus some amphibian species exhibit thermoregulating behaviours that put them at risk of exposure to increased UVR. For instance, to increase body temperature, and thus rate of growth and development, adult female amphibians may oviposit their eggs in, and tadpoles may seek, microhabitats in full sun, such as shallow and surface water [45-47]. Accelerating development and reducing time to metamorphosis is particularly important for those amphibian species that develop in ephemeral aquatic habitats that will disappear through either evaporation or freezing. Developing quickly is also important for embryos and tadpoles that need to escape their environment for other reasons, such as predation [48]. Similar to tadpoles, adults may also thermoregulate behaviourally by basking in the sun, or may seek light gaps for mating purposes $[49,50]$.

The effects of UVR are well studied in amphibians and have been reviewed elsewhere [8, 11, 51-54]. Briefly, field and laboratory studies have shown that exposure to UVR can reduce survival, reduce growth, slow the rate of development, induce developmental malformations and abnormalities, reduce locomotor performance, and cause changes in metabolic rate and behaviour (Table 1). Such lethal and sublethal UVR effects have been observed in the embryos, larvae, metamorphs and adults of 
Table 1 Examples of the effects of UVR on amphibians

\begin{tabular}{|c|c|c|c|}
\hline UVR effect & Species & Light Source & References \\
\hline \multicolumn{4}{|l|}{ Survival } \\
\hline \multirow[t]{9}{*}{ Reduced embryonic survival (hatching success) } & Ambystoma gracile & Ambient sunlight & [178] \\
\hline & Anaxyrus boreas & Ambient sunlight & [100] \\
\hline & Limnodynastes peronii & Artificial lamps & [147] \\
\hline & Lithobates sylvaticus & Artificial lamps & [93] \\
\hline & Litoria aurea & Ambient sunlight & [177] \\
\hline & Pseudacris cadaverina & Ambient sunlight & [179] \\
\hline & Rana aurora & Ambient sunlight plus artificial lamps & [96] \\
\hline & Rana cascadae & Ambient sunlight & [100] \\
\hline & Taricha torosa & Ambient sunlight & [179] \\
\hline \multirow[t]{29}{*}{ Reduced larval survival } & Ambystoma laterale & Ambient sunlight plus artificial lamps & [181] \\
\hline & Ambystoma macrodactylum & Artificial lamps & {$[78,182]$} \\
\hline & Ambystoma maculatum & Ambient sunlight plus artificial lamps & [181] \\
\hline & Anaxyrus americanus & Ambient sunlight plus artificial lamps & [181] \\
\hline & & Artificial lamps & [93] \\
\hline & Bufo bufo & Ambient sunlight & {$[180,183]$} \\
\hline & Crinia signifera & Ambient sunlight & [114] \\
\hline & Hyla versicolor & Ambient sunlight plus artificial lamps & [181] \\
\hline & & Artificial lamps & [93] \\
\hline & Hypsiboas pulchellus & Artificial lamps & [69] \\
\hline & Ichthyosaura alpestris & Ambient sunlight & [81] \\
\hline & & Artificial lamps & [81] \\
\hline & Limnodynastes peronii & Artificial lamps & {$[62,65]$} \\
\hline & Lithobates clamitans & Ambient sunlight & [184] \\
\hline & & Ambient sunlight plus artificial lamps & [181] \\
\hline & & Artificial lamps & [93] \\
\hline & Lithobates pipiens & Ambient sunlight & [184-186] \\
\hline & & Artificial lamps & [58] \\
\hline & Lithobates septentrionalis & Ambient sunlight & [184] \\
\hline & Lithobates sylvaticus & Ambient sunlight & [188] \\
\hline & & Ambient sunlight plus artificial lamps & [181] \\
\hline & & Artificial lamps & [93] \\
\hline & Litoria verreauxii alpina & Ambient sunlight & [114] \\
\hline & Pelophylax perezi & Ambient sunlight & [180] \\
\hline & Pseudacris regilla & Ambient sunlight plus artificial lamps & [96] \\
\hline & & Artificial lamps & [102] \\
\hline & Rana aurora & Ambient sunlight plus artificial lamps & [96] \\
\hline & Rana cascadae & Ambient sunlight & {$[42,155]$} \\
\hline & & Artificial lamps & {$[102,155]$} \\
\hline \multirow[t]{5}{*}{ Reduced metamorph survival } & Anaxyrus americanus & Artificial lamps & [93] \\
\hline & Lithobates clamitans & Artificial lamps & [93] \\
\hline & Lithobates sylvaticus & Artificial lamps & [93] \\
\hline & Pseudacris regilla & Artificial lamps & [102] \\
\hline & Rana cascadae & Artificial lamps & [102] \\
\hline
\end{tabular}


Table 1 Examples of the effects of UVR on amphibians (Continued)

\begin{tabular}{|c|c|c|c|}
\hline UVR effect & Species & Light Source & References \\
\hline \multicolumn{4}{|l|}{ Growth and development } \\
\hline Reduced size at hatching & Rana temporaria & Ambient sunlight & [136] \\
\hline \multirow[t]{3}{*}{ Reduced larval size } & Ambystoma macrodactylum & Artificial lamps & {$[78,182]$} \\
\hline & Limnodynastes peronii & Artificial lamps & {$[62,147,168]$} \\
\hline & Lithobates blairi & Ambient sunlight & [189] \\
\hline \multirow[t]{2}{*}{ Reduced size at metamorphosis } & Lithobates sylvaticus & Artificial lamps & [93] \\
\hline & Rana temporaria & Artificial lamps & {$[63,190]$} \\
\hline Reduced embryonic development rate & Ambystoma macrodactylum & Ambient sunlight & [191] \\
\hline \multirow[t]{2}{*}{ Reduced larval development rate } & Lithobates blairi & Ambient sunlight & [189] \\
\hline & Lithobates pipiens & Artificial lamps & [58] \\
\hline \multirow[t]{2}{*}{ Reduced development rate to stage 25 [192] } & Limnodynastes peronii & Artificial lamps & [65] \\
\hline & Rana temporaria & Artificial lamps & [193] \\
\hline Longer time to hatching & Limnodynastes peronii & Artificial lamps & {$[65,168]$} \\
\hline \multirow[t]{2}{*}{ Longer time to metamorphosis } & Lithobates pipiens & Artificial lamps & [58] \\
\hline & Rana temporaria & Artificial lamps & {$[63,190]$} \\
\hline \multicolumn{4}{|l|}{ Malformations and abnormalities } \\
\hline \multirow[t]{14}{*}{ Spinal curvature } & Ambystoma macrodactylum & Ambient sunlight & [191] \\
\hline & Anaxyrus boreas & Artificial lamps & {$[194,195]$} \\
\hline & Hypsiboas pulchellus & Artificial lamps & [69] \\
\hline & Limnodynastes peronii & Artificial lamps & [65] \\
\hline & Lithobates clamitans & Artificial lamps & [93] \\
\hline & Lithobates pipiens & Artificial lamps & [58] \\
\hline & Lithobates sylvaticus & Ambient sunlight & [188] \\
\hline & & Artificial lamps & [93] \\
\hline & Pleurodema bufoninum & Ambient sunlight & [92] \\
\hline & & Artificial lamps & [92] \\
\hline & Pseudacris regilla & Artificial lamps & [102] \\
\hline & Rana temporaria & Artificial lamps & [63] \\
\hline & Rhinella arenarum & Artificial lamps & [187] \\
\hline & Xenopus laevis & Artificial lamps & [196] \\
\hline \multirow[t]{8}{*}{ Edema } & Ambystoma macrodactylum & Ambient sunlight & [191] \\
\hline & Lithobates pipiens & Artificial lamps & [58] \\
\hline & Lithobates sylvaticus & Ambient sunlight & [188] \\
\hline & Pleurodema bufoninum & Ambient sunlight & [92] \\
\hline & & Artificial lamps & [92] \\
\hline & Pseudacris regilla & Artificial lamps & [102] \\
\hline & Rana cascadae & Artificial lamps & [102] \\
\hline & Rhinella arenarum & Artificial lamps & [187] \\
\hline Underdeveloped gills & Rhinella arenarum & Artificial lamps & [187] \\
\hline \multirow[t]{5}{*}{ Eye abnormalities } & Anaxyrus boreas & Artificial lamps & {$[194,195]$} \\
\hline & Lithobates pipiens & Ambient sunlight & [185] \\
\hline & Rana aurora & Ambient sunlight plus artificial lamps & [198] \\
\hline & Rana cascadae & Artificial lamps & [199] \\
\hline & Pseudacris regilla & Ambient sunlight plus artificial lamps & [198] \\
\hline
\end{tabular}


Table 1 Examples of the effects of UVR on amphibians (Continued)

\begin{tabular}{|c|c|c|c|}
\hline UVR effect & Species & Light Source & References \\
\hline & Xenopus laevis & Artificial lamps & [196] \\
\hline \multirow[t]{4}{*}{ Limb and digit malformations } & Hypsiboas pulchellus & Artificial lamps & [69] \\
\hline & Lithobates pipiens & Ambient sunlight & {$[185,186]$} \\
\hline & & Artificial lamps & {$[58,200]$} \\
\hline & Rana temporaria & Artificial lamps & [63] \\
\hline Jaw malformations & Hypsiboas pulchellus & Artificial lamps & [69] \\
\hline \multicolumn{4}{|l|}{ Locomotion performance } \\
\hline Reduced larval escape swimming speed & Limnodynastes peronii & Artificial lamps & {$[65,168]$} \\
\hline Reduced metamorph jumping performance & Hypsiboas pulchellus & Artificial lamps & [69] \\
\hline \multicolumn{4}{|l|}{ Metabolism } \\
\hline \multirow[t]{2}{*}{ Reduced whole-animal metabolic rate in larvae } & Bufo bufo & Artificial lamps & [197] \\
\hline & Limnodynastes peronii & Artificial lamps & [37] \\
\hline Increased whole-animal metabolic rate in larvae & Bufo bufo & Artificial lamps & [197] \\
\hline Increased tissue metabolic rate in larvae & Limnodynastes peronii & Artificial lamps & {$[37]$} \\
\hline \multicolumn{4}{|l|}{ Behaviour } \\
\hline \multirow[t]{3}{*}{ Erratic swimming behaviour } & Ichthyosaura alpestris & Ambient sunlight & [81] \\
\hline & & Artificial lamps & [81] \\
\hline & Lithobates sylvaticus & Artificial lamps & [93] \\
\hline \multirow[t]{2}{*}{ Swimming in circles } & Lithobates pipiens & Artificial lamps & {$[58]$} \\
\hline & Lithobates sylvaticus & Artificial lamps & [93] \\
\hline \multirow[t]{5}{*}{ Reduced activity levels } & Hyla versicolor & Artificial lamps & [90] \\
\hline & Limnodynastes peronii & Artificial lamps & {$[37]$} \\
\hline & Rana aurora & Artificial lamps & {$[88]$} \\
\hline & Rana cascadae & Artificial lamps & [155] \\
\hline & Xenopus laevis & Artificial lamps & {$[90]$} \\
\hline Reduced predator avoidance & Anaxyrus boreas & Artificial lamps & [64] \\
\hline \multirow[t]{4}{*}{ Changed microhabitat use } & Ambystoma barbouri & Ambient sunlight & [80] \\
\hline & Ambystoma texanum & Ambient sunlight & {$[80]$} \\
\hline & Oophaga pumilio & Ambient sunlight & [201] \\
\hline & & Ambient sunlight plus artificial lamps & [201] \\
\hline
\end{tabular}

several amphibian species in North America, Europe, Australia and South America. However, UVR sensitivity varies among life stages, populations and species for many response variables [11]. Though importantly, a quantitative meta-analysis of 89 studies of the effects of ambient UVBR on embryonic and larval survival found that, on average, UVBR exposure reduces survival by nearly half [55].

By increasing the mortality of embryos, larvae and metamorphs, increased UVR will likely have adverse effects on fitness, reduce recruitment in a population, and thus contribute to population decline ([56], but see [57]). Whether sublethal UVR effects similarly reduce fitness and contribute to reduced recruitment is less well known, but seems probable. Croteau et al. [58] demonstrated that UVR-induced spinal curvature in tadpoles ultimately causes them to starve to death because their swimming ability is compromised and thus are unable to forage. UVR-induced malformations of the eyes and limbs may also negatively affect foraging ability, predator evasion, and reproductive success, but these possibilities have not been tested directly. Other studies have measured correlates of fitness such as locomotor performance [59], anti-predator morphology and behaviour [60], and age and size at metamorphosis [61], and have demonstrated that these are negatively impacted by exposure to UVR [62-65]. Only two studies that we know of have used predation trials to determine that exposure to increased UVR increases the susceptibility of tadpoles to predation [66, 67]. Romansic et al. [67] attributed this increased susceptibility to predation to UVR-induced tail deformities that may have impaired tadpole swimming 
ability. Alton et al. [66], on the other hand, found no effect of increased UVR exposure on either tadpole morphology or escape swimming performance. Consequently, Alton et al. [66] cautioned that fitness proxies are not necessarily reliable for inferring changes in fitness, and as such, fitness should be measured directly. It therefore follows that measures of adult reproductive success and output are needed if we are to understand the effect of UVR on fitness and recruitment within a population. Currently there is limited research that suggests that UVR exposure during early life can have carry-over effects on later life stages following metamorphosis $[68,69]$.

\section{Amphibian defences against UVR}

Like other organisms, amphibians have evolved a number of defences against the damaging effects of UVR, including behavioural avoidance and the molecular defences discussed in the section "Defences against UVR damage" (e.g. UVR-screening compounds, antioxidants, heat shock proteins, photoreactivation, and excision repair). Behavioural avoidance of UVR through the utilisation of UVR-protected habitats is a simple and effective defence mechanism that is relatively well studied in amphibians. The protective function of melanin and other UVR-screening compounds in amphibians in not well understood, but has been examined for numerous species. Similarly, the function of the egg jelly envelope that surrounds the amphibian embryo as a physical UVRscreening substance has also been considered for numerous amphibian species. However, the protective screening role of the superficial mucus layer on tadpoles has not been considered, nor is it known if amphibians are able to accumulate screening compounds through their diet. In amphibians, neither antioxidants nor heat shock proteins have been well studied, but in response to UVR exposure, the activity and concentration of the antioxidant, superoxide dismutase, has been shown to increase [70, 71], whereas the activity of catalyse does not [72], and the abundance of the heat shock protein, hsp72, increases following heat shock [72]. The DNA repair mechanism of photoreactivation has been examined in numerous amphibian species, but less is known of excision repair. In the following sections we review the UVR defence mechanisms of amphibians for which most is known (behavioural avoidance, UVR-screening compounds and egg jelly, and DNA repair).

\section{Environmental protection and behavioural avoidance}

As discussed in the section "Ultraviolet radiation", exposure of amphibians to UVR is dependent on geophysical and atmospheric parameters, such as latitude, altitude, ozone and cloud cover, as well as the UVRfiltering properties of the environment such as vegetative cover and dissolved organic carbon (DOC) (Fig. 2). Assessments of UVR exposure in amphibian breeding habitats have been undertaken at various locations in North America to establish the threat posed by UVR [73-76]. Such studies have determined that the DOC levels and landscape parameters (such as topography and vegetation) in the majority of breeding habitats offer protection from doses of UVR known to cause mortality and malformations in the embryos of selected amphibian species [73, 74, 76]. In contrast, Olker et al. [75] determined that UVR exposure in vernal pools in northern Minnesota is sufficiently high at or near the water surface to reduce larval survival, delay larval development and metamorphosis, and induce malformations. While such characterisations of the photic environment in amphibian habitats are critical to evaluating the role of UVR in amphibian declines, these studies have only considered the UVR levels necessary to induce mortality, some sublethal effects, and no interactive effects (see the section "Interactive effects of UVR with other environmental factors"). Consequently, the threat posed by UVR may be underestimated. An understanding of the behavioural response of amphibians to UVR is also generally lacking from such studies ([74], but see [75]), and as Diamond et al. [73] say, is "the greatest single source of uncertainty" in such assessments. Oviposition site choice by adult females, the nature of larval phototaxis (i.e. are they attracted to or avoid light?), depth and microhabitat choice by larval amphibians, how these behaviours change temporally and ontogenetically, and how these behaviours are influenced by other environmental factors are necessary considerations when evaluating the risk of UVR exposure to specific species and populations.

The behavioural response of adult and larval amphibians to UVR has been examined for a number of species. For adult females, the use of UVR-protected microhabitats for oviposition varies among species and populations. Species with embryos that are more sensitive to UVR due to relatively poor physiological UVR defences have been observed to oviposit more frequently in UVRprotected habitats, such as in deeper water and in the shade [76]. Similarly, populations of long-toed salamander Ambystoma macrodactylum at high elevations where UVR incidence is greater utilise UVR protected microhabitats, whereas populations at low elevations do not [77]. For larvae, choice experiments have revealed that some species have a preference for shaded habitats (negative phototaxis) but do not specifically avoid UVR $[78,79]$, some species avoid UVR despite having a preference for unshaded habitats (positive phototaxis) $[80,81]$, and some species are positively phototactic but do not specifically avoid UVR [82]. Species that prefer shaded or deep-water habitats are coincidentally protected 
from anthropogenic increases in UVR despite showing no specific avoidance of UVR. Species that prefer unshaded habitats but choose to avoid UVR by moving into deeper water or hiding in refuges risk facing other environmental challenges such as suboptimal temperatures, fewer opportunities to feed, or increased risk of predation [80]. In contrast to those species that prefer shaded habitats or avoid UVR exposure, species that choose to occupy shallow water habitats regardless of exposure to UVR are at risk of exposure to increased environmental UVR. However, species that exhibit this behaviour appear to select these microhabitats to meet their thermoregulatory needs [82].

While several environmental factors dictate oviposition site and microhabitat choices in amphibians, the variation in their observed behavioural responses to UVR shows that UVR is a strong selective pressure for some species, such that they will avoid it even in the presence of other environmental challenges. For other species, it appears that they rely more on physiological UVR defences (see the sections "UVR-screening compounds and egg jelly" and "DNA repair mechanisms"), and less on behavioural avoidance. It may also be that those species for which thermoregulation appears to be a stronger selective force than UVR avoidance, are ultimately exposed to lower cumulative UVR doses because of faster development rates that allow them to escape their aquatic environment, and thus further UVR exposure. Regardless, behavioural avoidance of UVR is likely to be an important defence mechanism in the face of evolutionarily rapid increases in environmental UVR that have occurred as a result of ozone depletion [83]. Consequently, those species that do not behaviourally avoid UVR may be negatively impacted by increased UVR if their physiological UVR defences cannot provide sufficient protection against UVR-induced damage and show no acclimatory or adaptive capacity.

\section{UVR-screening compounds and egg jelly}

Pigments in the eggs and skin of amphibians, including melanin, may act as UVR-screening compounds that prevent UVR damage from occurring [51]. In the European common frog Rana temporaria, Hofer and Mokri [84] identified a non-melanic substance localised in the skin of tadpoles that has a peak absorbance in the UVBR waveband and increases in concentration in response to UVAR and UVBR exposure. Hofer and Mokri [84] hypothesised that the presence of this UVBRabsorbing substance may be one of the reasons that the survival of $R$. temporaria embryos and tadpoles is unaffected by exposure to ambient and elevated UVBR levels [84, 85]. However, Hofer and Mokri [84] also speculated that accumulation of melanin at the skin surface (i.e. skin darkening) may also protect $R$. temporaria embryos and tadpoles from UVR damage.
Skin darkening in response to UVR exposure has been observed for a number of amphibian species [80, 86-90]. However, the effectiveness of skin darkening in protecting amphibians from UVR damage is not well understood. Skin darkening in amphibians is mediated by the dispersion of melanin-filled pigment granules (melanosomes) within dermal pigment cells (melanophores). Using in vitro skin samples from the Indian bullfrog Hoplobatrachus tigerinusi, Ali et al. [91] determined that melanosome dispersion is induced by low doses of UVR, but that higher UVR doses cause melanophores to rupture and undergo apoptosis. Belden and Blaustein [86] found that UVR exposure induces melanosome dispersion in vivo in the skin of larval roughskin newt Taricha granulosa and northwestern salamander Ambystoma gracile. However, inducing increased melansome dispersion by rearing larvae against a dark background did not prevent UVR exposure from reducing the growth of long-toed salamander A. macrodactylum and A. gracile [86]. Together this research suggests that melanin may not be effective at protecting larval amphibians from damaging levels of UVR.

The protective function of melanin has also been examined in the embryos of a number of amphibian species. Lesser et al. [71] determined that UVR exposure induces increased melanin production in spotted salamander A. maculatum embryos. However, despite having increased melanin, embryos exposed to UVR suffered greater DNA damage in the form of CPDs, had reduced survival, and upon hatching, were smaller in size [71]. In contrast to this, Perotti and Diéguez [92] found that embryonic melanin concentration is positively correlated with UVR exposure experienced in the environment, suggesting that pigmentation may indeed be an adaptive photoprotective mechanism for this life stage. Perotti and Diéguez [92] found that of three Patagonian amphibian species, the species that oviposits in deep water with high UVR absorbance and experiences the lowest UVR exposure had the lowest embryonic melanin concentration (Chile four-eyed frog Pleurodema thaul). The species that oviposits in shallow water with low UVR absorbance and experiences the highest UVR exposure had the highest embryonic melanin concentration (warty toad Rhinella spinulosa). Perotti and Diéguez [92] also found that the optical properties of the egg jelly envelope surrounding the embryo is also correlated with embryonic melanin concentration: the egg jelly of the species with the lowest embryonic melanin concentration ( $P$. thaul) had the highest UVR absorbance whereas the egg jelly of the species with the highest embryonic melanin concentration ( $R$. spinulosa) had the lowest UVR absorbance. Several additional studies have similarly shown that the UVR absorbance by the egg jelly envelope varies with wavelength and among species [93-97], and also the protective role of the jelly envelope 
varies among populations within a species along an elevation gradient [98]. Such research indicates that for some species the jelly envelope may provide adequate protection against UVR for the embryo, whereas others may rely on alternative defence strategies such as pigmentation, behavioural avoidance (e.g. [92]), or efficient DNA repair mechanisms [97].

\section{DNA repair mechanisms}

In amphibians, the repair of UVR-induced DNA damage by photoreactivation has been examined for a number of species. Specifically, embryonic CPD photolyase activity has been quantified for a number of North American amphibian species [77, 97, 99-102], as well as three Australian species [103]. Such research has demonstrated that a correlation exists between CPD photolyase activity and UVR sensitivity, with embryos exhibiting relatively low photolyase activity suffering greater mortality than those with high CPD photolyase activity. In addition, CPD photolyase activity also appears to be correlated with expected UVR exposure in the natural environment [97, 100]. For example, most salamander species hide their eggs from sunlight or lay them in relatively deep water where there is significant attenuation of UVR, are highly sensitive to UVR, and show little CPD photolyase activity [100]. Pacific tree frog Pseudacris regilla, on the other hand, is an anuran species that lays its eggs in open water exposed to sunlight, has high CPD photolyase activity levels, and is not negatively affected by UVR exposure [100]. Thurman et al. [77] evaluated the association between oviposition site choice, embryonic UVR exposure and CPD photolyase activity in long-toed salamander Ambystoma macrodactylum among high- and low-elevation populations and found that there was no significant difference in CPD photolyase activity among populations. Rather, A. macrodactylum populations exhibit differences in their oviposition site choice such that embryonic UVR exposure is no different between the high- and low-elevation populations.

The study by Thurman et al. [77] and such comparative studies as that by Blaustein et al. [100] demonstrate that, for at least some species, UVR-moderating behaviours and other photoprotective mechanisms (e.g. UVRscreening compounds and egg jelly) may be effective at minimising the exposure of amphibians to UVR, and consequently reduce the selection pressure for effective DNA repair mechanisms [104]. Some species, however, do not exhibit UVR avoidance behaviours such as the golden bell frog Litoria aurea, Cascades frog Rana cascadae and boreal toad Anaxyrus boreas who lay their eggs in shallow water exposed to sunlight, and have low DNA repair capabilities [100, 103]. These three species are suffering population declines and it has been proposed that increased UVR may be a contributing factor.
Whether or not amphibians are able to physiologically acclimate and adapt to changes in UVR levels through changing their DNA repair efficiencies has not been examined. However, such studies will be important for determining the threat posed by UVR to species such as $L$. aurea, $R$. cascadae and A. boreas.

\section{Interactive effects of UVR with other environmental factors}

In light of the now general understanding that amphibian declines are more likely to be a result of complex interactions between multiple environmental factors as opposed to single factors acting independently $[7,8,56,105,106]$, multi-factorial studies have been identified as a key area of research that is needed to disentangle the underlying mechanisms behind global amphibian declines [8, 107, 108]. Controlled multi-factorial experimental studies are necessary because the combined effect of multiple environmental factors cannot always be predicted from single-factor studies. In cases where interactive effects can be predicted from single-factor studies, the interaction is known as additive because it is equal to the sum of the effects caused by the factors independently [109]. In cases where interactive effects cannot be predicted from single-factor studies, the effect of the combined factors is either greater than, or less than, the sum of the independent effects, and are known as synergistic and antagonistic interactions, respectively [109]. Given that environmental factors are able to interact in such ways, examination of the effects of UVR in the absence of other environmental factors potentially oversimplifies and underestimates the actions of UVR in natural systems. Consequently, a growing body of research has been devoted to understanding how UVR impacts upon amphibians when combined with other abiotic (contaminants, temperature, aquatic $\mathrm{pH}$ and aquatic hypoxia) and biotic (infectious disease, conspecific density and predation) factors. A quantitative factorial meta-analysis of such early research indicated that UVR interacts synergistically with an additional factor to increase amphibian mortality [55], though contaminants were the predominant additional factor in this analysis. Here we focus on, and describe, the interactive effects of UVR combined with a range of naturally occurring abiotic (temperature, aquatic $\mathrm{pH}$ and aquatic hypoxia) and biotic factors (infectious disease, conspecific density and predation).

\section{UVR and abiotic factors \\ Temperature}

Temperature is one of the most important physical properties of the environment and varies over a range of 
spatial and temporal scales. It has a profound effect on ectotherms, such as amphibians, as it influences their physiology, behaviour and ecology [47, 110]. Within limits, increasing temperature accelerates most physiological processes, and thus in amphibians, environmental temperature affects rate of growth and development, time to metamorphosis, body size at metamorphosis, metabolic rate and many other processes [47]. The thermal tolerance of an organism dictates the temperature range over which activity and survival is possible and is therefore associated with the geographic distribution of a species $[47,110]$. The thermal optimum for an ectotherm is the temperature at which its biochemical and physiological processes operate best and is related to its preferred body temperature [47, 110]. The preferred body temperature of an ectotherm, along with other factors, therefore influences how an ectotherm moves and behaves among the available thermal microenvironments [110]. Given that both UVR and temperature influence behaviour and physiological functions, there is potential for UVR and temperature to give rise to interactive effects in amphibians via these two pathways.

Currently, there is little known about the combined influence of UVR and temperature on behaviour in amphibians. Bancroft et al. [82] found that tadpoles of the boreal toad Anaxyrus boreas and Pacific tree frog Pseudacris regilla select their preferred environmental temperature regardless of UVR exposure, and reside in shallow water in the middle of the day where temperatures and UVR doses are high. Consequently, Bancroft et al. [82] proposed that for these species, temperature is a stronger selective force than UVR because of the intense pressure to develop rapidly and metamorphose before their habitat disappears. However, separate studies have shown that UVR exposure can be detrimental to these species, though more so for $A$. boreas [100, 111-113]. Consequently, choosing warm surface waters exposed to UVR may have negative consequences for the growth, development, performance and survival of these species, though this has not been tested directly.

Behaviour is not the only pathway by which UVR and temperature can interact. Lower temperatures have been found to prolong the time to hatch, and thus the length of exposure to UVR, resulting in morphological and behavioural abnormalities in wood frog Rana sylvatica embryos [93] and increased mortality and frequency of developmental abnormalities in embryos of the striped marsh frog Limnodynastes peronii [65]. However, lower temperatures have also been found to enhance the negative effects of UVR independent of exposure duration. Using a fixed exposure duration, Broomhall et al. [114] found that the embryos and tadpoles of the alpine tree frog Litoria verreauxii and brown froglet Crinia signifera suffered greater mortality when exposed to UVR at higher elevations where temperatures were cooler. However, because temperature was confounded with elevation, Broomhall et al. [114] could not attribute the greater effect of UVR at higher elevations to cooler temperatures specifically. van Uitregt et al. [65] on the other hand, confirmed that cooler temperatures enhance the negative effects of UVR independent of exposure duration by using a controlled laboratory experiment: they found that despite the same exposure duration, the negative effect of UVR on the survival, growth and locomotor performance of $L$. peronii tadpoles was greater at $20{ }^{\circ} \mathrm{C}$ than at $30{ }^{\circ} \mathrm{C}$. Broomhall et al. [114] and van Uitregt et al. [65] both hypothesised that the apparent thermal-dependence of UVR effects may therefore also be due to the reduced activity of the enzymes involved in defending against UVR damage at lower temperatures.

The thermal sensitivity of the biochemical reactions involved in preventing and repairing UVR-induced damage within cells (discussed in the section "Defences against UVR damage") has not been well studied in amphibians. Only the activity of the antioxidant enzyme catalase has been shown not to be thermally sensitive in response to UVR exposure in L. peronii tadpoles [72]. However, the DNA repair mechanisms of enzymatic photoreactivation (EPR) and nucleotide excision repair (NER) have been shown to increase with increasing temperature in ciliates [115], freshwater crustaceans [116], marine macroalgae [117], tobacco cells [118] and echinoid embryos [119], however, Connelly et al. [120] found the opposite to be true in Daphnia. The photoprotective mechanism of ROS reduction by enzymatic antioxidant activity has also been found to be thermally sensitive in summer-caught mosquito fish Gambusia holbrooki exposed to UVR [39]. Kazerouni et al. [39] found that the activities of superoxide dismutase and catalase were highest in fish acclimated to the average environmental temperature of $28{ }^{\circ} \mathrm{C}$, but was reduced in fish acclimated to lower and higher temperatures $\left(18{ }^{\circ} \mathrm{C}\right.$ and $\left.32{ }^{\circ} \mathrm{C}\right)$. Importantly, the improved efficiency of EPR, NER and antioxidant activity due to changes in temperature has been found to reduce the negative effects associated with UVR exposure on development, survival, metabolic rate and locomotor performance $[39,119,120]$. Given that EPR, NER and antioxidant activity are thermally sensitive in other organisms, it seems likely that these physiological UVR defences are also thermally sensitive in amphibians. It is therefore possible that increased UVR due to stratospheric ozone may have contributed to the enigmatic amphibian declines at high elevations because the cooler temperatures of these environments may have impaired the ability of amphibians to defend themselves against the relatively high UVR doses experienced at these elevations. However, this remains to be tested. 
High temperatures, like low temperatures, may also exacerbate the negative effects of UVR by impairing the function of the enzymes involved in defending against UVR damage, as has been found in summer-caught mosquito fish Gambusia holbrooki [39]. Many amphibian species develop in shallow, ephemeral water bodies where temperatures can fluctuate widely on a daily time scale, and thus exposure to high UVR doses is likely to coincide with high temperatures (greater than $35^{\circ} \mathrm{C}$ ) in the middle of the day [47, 121, 122]. Alton and Franklin [123] attempted to address the question of whether exposure to peak UVR levels while temperature is high $\left(35{ }^{\circ} \mathrm{C}\right)$ is more detrimental to pre-metamorphic $L$. peronii than exposure to peak UVR levels while temperature is moderate $\left(25^{\circ} \mathrm{C}\right)$ using an ecologically relevant fluctuating UVR and temperature regime. Alton and Franklin [123] found that embryos exposed to peak UVR levels at $35{ }^{\circ} \mathrm{C}$ hatched $10 \mathrm{~h}$ later than those exposed to peak UVR levels at $25^{\circ} \mathrm{C}$, and as tadpoles, were smaller and consequently swam slower, but in a predator environment exhibited no difference in survival time. Kern et al. [121], on the other hand, reared ornate burrowing frog Platyplectrum ornatum tadpoles in a fluctuating temperature regime that oscillated daily between $18{ }^{\circ} \mathrm{C}$ and $32{ }^{\circ} \mathrm{C}$ and found that exposure to UVR while the temperature was high reduced their survival and body mass, but increased their critical thermal maximum $\left(\mathrm{CT}_{\max }\right)$. The study by Kern et al. [121] is interesting in that it suggests that synchronous exposure to peak levels in UVR and temperature can have both negative and positive effects on larval amphibians. Kern et al. [121] proposed that the positive effect of UVR exposure on the $\mathrm{CT}_{\max }$ may be due to the induction of heat shock proteins that are important for determining the critical thermal maximum. In a follow up study on $L$. peronii, Kern et al. [72] found that UVR exposure does indeed increase the abundance of the heat shock protein, hsp72, following heat shock. However, contrary to their previous study, exposure to UVR did not affect the $\mathrm{CT}_{\max }$ of tadpoles reared under a fluctuating temperature regime $\left(18-28{ }^{\circ} \mathrm{C}\right)$. Instead, exposure to UVR increased the $\mathrm{CT}_{\max }$ of tadpoles reared at a stable low temperature of $18{ }^{\circ} \mathrm{C}$, and reduced the $\mathrm{CT}_{\max }$ of tadpoles reared at a stable high temperature of $28^{\circ} \mathrm{C}$.

Research on the interactive effects of UVR and temperature on amphibians have thus far demonstrated that temperature may be a stronger selective force than UVR. Consequently, thermoregulating behaviours may put amphibians at risk of exposure to damaging doses of UVR. Research has also shown that lower temperatures can exacerbate the negative effects of UVR by slowing development rate and prolonging exposure to UVR, and possibly by reducing the efficiency of physiological UVR defences. However, the potential of UVR exposure to induce heat shock proteins and increase the thermal tolerance of some amphibian species under certain conditions indicates that the interactive effects of UVR and temperature are not always negative. Studies that examine the thermal sensitivity of physiological UVR defences are lacking in amphibians, but are needed to better understand the pathways but which interactive effects arise when these two environmental variables are considered. While studying the effects of UVR under stable thermal conditions will help us to derive conclusions about the direct influence of temperature on the function of physiological UVR defence mechanisms, research on the effects of UVR under fluctuating thermal conditions will be more ecologically relevant but more difficult to interpret.

\section{Aquatic $\mathrm{pH}$}

Aquatic $\mathrm{pH}$ varies naturally within several freshwater environments worldwide with many being acidic because of naturally occurring humic acids, or the biological activity of Sphagnum ([47] and references therein). For example, the 'wallum' freshwater environments along the eastern coast of Australia are naturally low in $\mathrm{pH}$ with the larvae of wallum-endemic 'acid frog' species recorded in waters with a pH between 3 and 4 [124]. In North America, Carpenter frog Lithobates virgatipes and pine barren treefrog Hyla andersoni are characteristic species of the New Jersey pine barrens and breed in sphagnum bogs and swamps with a $\mathrm{pH}$ ranging from 3.6 to 5.2 [125]. Spawn of the European common frog Rana temporaria have been observed in ponds ranging in $\mathrm{pH}$ from 4.2 to 8.9 in northern England [126], and the adults and larvae of alpine newt Mesotriton alpestris have been found in ponds ranging in $\mathrm{pH}$ from 4.5 to 9.3 in the Tyrolean Alps [81]. Research on the effects of aquatic $\mathrm{pH}$ on amphibians has concentrated on the effects of acidic water due to concerns of anthropogenic environmental acidification arising from sulphur and nitrogen oxide emissions [127-129]. In larval amphibians, exposure to low $\mathrm{pH}$ adversely affects osmoregulation primarily through damage to the gill epithelium that results in a net loss of sodium ions $[130,131]$. Low $\mathrm{pH}$ has been shown to cause increased mortality of embryos and larvae, decreased growth, increased developmental time, and changes in the outcome of competitive and predator-prey interactions (see [132] and references therein). Less is known of the effects of alkaline water on amphibians, but Fominykh [133] found that high $\mathrm{pH}$ (9.0-9.5) retards larval development in three amphibian species leading to mortality prior to metamorphosis.

Thus far, the interactive effects of UVR and aquatic $\mathrm{pH}$ have only considered the interaction between UVR and low pH. Long et al. [134] investigated the potential for interactive effects between UVR and low $\mathrm{pH}$ on 
northern leopard frog Lithobates pipiens embryos and found that separately, UVR and low pH had no effect on hatching success, but when combined, UVR and low $\mathrm{pH}$ interacted synergistically to reduce hatching success. In contrast, Pahkala et al. [135] found that exposure to low $\mathrm{pH}$ (5.0) caused the embryos of moor frog Rana arvalis to have reduced hatching success, increased frequency of developmental abnormalities and reduced size at hatch, but were unaffected by exposure to ambient UVR with no evidence of an interaction between these two factors. Pahkala et al. [136] found that $R$. temporaria embryos were similarly affected by low $\mathrm{pH}$ (5.0), and though size at hatch was reduced by exposure to ambient UVR, they also found no interaction between these two factors. However, in a follow up study on $R$. temporaria, Pahkala et al. [137] found population differences in the response of embryos to UVR and low $\mathrm{pH}$ (4.5). Independently, UVR and low $\mathrm{pH}$ had no effect on the hatching success or frequency of developmental abnormalities in embryos from northern Sweden [137]. However, when exposed to UVR in combination with low $\mathrm{pH}$, embryos showed markedly reduced survival and increased frequency of developmental abnormalities [137]. Such synergistic effects were not evident in embryos from southern Sweden, nor was there evidence of an interactive effect for the response variables of developmental rate and hatching size in either population [137]. Pahkala et al. [137] proposed that the lack of a UVR-pH synergism in the southern $R$. temporaria population may be the consequence of an evolved tolerance to low $\mathrm{pH}$ associated with a long-term increase in environmental acidification across southern Sweden.

The work by Long et al. [134] and Pahkala et al. [137] demonstrates that there is potential for UVR to interact synergistically with low aquatic $\mathrm{pH}$ to have negative effects on developing amphibians. However, the pathways by which these interactive effects arise remain unknown. One potential pathway relates to the energetic costs associated with maintaining osmotic balance in an acidic environment and the energetic costs associated with defending against UVR-induced cellular damage. If being exposed to low aquatic $\mathrm{pH}$ and UVR increases the maintenance costs of embryos and tadpoles then they will have less energy available for growth and other physiological processes necessary for development and survival. Interactive effects may also arise in tadpoles as a consequence of the physical damage to the gill tissue caused by both UVR and low aquatic $\mathrm{pH}$, which may impede their ability to osmoregulate and respire. Alternatively, the work by Pahkala et al. [137] suggests that if amphibians are well adapted to the osmotic challenges associated with acidic environments, then increased UVR exposure may not result in synergistic effects. Given that amphibians are known to live across a wide range of natural $\mathrm{pH}$ levels, more research is needed on the interactive effects of UVR and aquatic pH, particularly alkaline $\mathrm{pH}$, to better understand how these factors in combination might impact amphibian populations.

\section{Aquatic hypoxia}

Aquatic hypoxia is a pervasive environmental stressor that occurs naturally as a result of changes in water temperature, stratification of the water column, and high numbers of respiring aquatic organisms [47, 138, 139]. Amphibians encounter aquatic hypoxia in a range of breeding habitats [132], including those that are shallow and ephemeral (e.g. [140]), and this can have profound effects on developing embryos and tadpoles. Aquatic oxygen levels lower than $12.2 \mathrm{kPa}$ are known to delay embryonic development and, in some cases, can increase rates of embryonic and larval mortality [140-142]. Aquatic hypoxia can also induce physiological and behavioural changes in tadpoles including increased activity levels, ventilatory frequency, and the frequency of aerial respiration [143, 144]. Non-air-breathing tadpoles, however, can only survive for short periods of time in waters with low levels of aquatic oxygen [145, 146].

In the only study to examine the interactive effects of UVR and aquatic hypoxia, Bernal et al. [147] found that embryonic and larval striped marsh frog Limnodynastes peronii were more sensitive to aquatic hypoxia than UVR. Exposure to aquatic hypoxia $(4-5 \mathrm{kPa})$ reduced embryonic hatching success, tadpole survival, tadpole body mass, and tadpole locomotor performance. Exposure to UVR on the other hand reduced only embryonic hatching success and tadpole body mass, and these effects were smaller than that caused by aquatic hypoxia. However, UVR and aquatic hypoxia interacted additively to produce an effect on embryonic hatching success and tadpole body mass that was greater than the effect of either factor in isolation. The pathways that led to these additive effects are unknown, but it may be that embryos and tadpoles may have had less oxygen available for the production of ATP, which then constrained the effectiveness of their UVR defences. It is also possible that aquatic hypoxia caused tadpoles to spend more time near the water surface where oxygen levels may have been higher but where UVBR exposure was greater. These hypotheses require testing and thus further research is needed on the interactive effects of UVBR and aquatic hypoxia.

\section{UVR and biotic factors Infectious disease}

Infectious disease is considered to be the third most significant threat to amphibians, following habitat loss and pollution [2]. Pathogens known to cause infectious disease in amphibians that may contribute to population 
declines include the fungi Batrachochytrium dendrobatidis and B. salamandrivorans, the protozoan water mould Saprolegnia ferax, the iridovirus Ranavirus sp., and the trematode parasite Ribeiroia sp. [56, 148]. While infectious disease, most notably chytridiomycosis caused by $B$. dendrobatidis $(\mathrm{Bd})$, is posited to be the proximate cause of most enigmatic amphibian declines [149], it remains unclear why the susceptibility of amphibians to disease appears to have increased only recently. However, two non-mutually exclusive hypotheses have been put forward [150]: one hypothesis is that novel pathogens have emerged recently either because they have evolved recently, or because they have spread into new geographic areas with naïve individuals or species; and the other hypothesis is that recent anthropogenic environmental change has caused pathogens to become more prevalent either by enhancing their growth/virulence, or by compromising the immune response of the amphibian host making them more susceptible to infection.

Increased environmental UVBR may contribute to the role of diseases in population declines by causing local and systemic immunosuppression, making amphibians more susceptible to viral, fungal and bacterial infections [151, 152]. UVR-induced immunosuppression occurs via a number of different pathways that will not be discussed in detail here. Briefly, UVR exposure can cause immunosuppression by inhibiting antigen presentation, inducing the release of immunosuppressive cytokines, reducing phagocytosis by macrophages, suppressing natural cytotoxicity activity, and inducing the stress response $[41,152,153]$. The mechanisms of UVR-induced immunosuppression have been studied predominantly in mammals, but given that the innate and adaptive immune system of amphibians is similar to that of mammals [151], it is likely that these immunosuppressive mechanisms also occur in amphibians. In the only study to examine the effect of UVR exposure on indices of immune function in an amphibian, it was found that exposure to UVR during early larval life caused metamorphs, but not older tadpoles, to have reduced white blood cell count and a reduced swelling response to a foreign antigen challenge [68]. This finding shows that UVR exposure does indeed cause immunosuppression in amphibians, but interestingly this effect may only become apparent following metamorphosis.

Indirect evidence for UVR-induced immunosuppression in amphibians was found by Kiesecker and Blaustein [112] for boreal toad Anaxyrus boreas and Cascades frog Rana cascadae. They experimentally demonstrated in the field that simultaneous exposure to $S$. ferax and UVR caused greater embryonic mortality than exposure to either factor alone indicating that UVR exposure may have increased their vulnerability to infection. In a follow up study, Kiesecker et al. [113] revealed that the complexity of this system goes beyond the synergistic effects of UVR and S. ferax by showing that climate change influences UVR exposure of amphibians in the field. Using long-term observational data and a field experiment, they found that climate-induced reductions in water depth at oviposition sites caused high mortality of $A$. boreas embryos by increasing their exposure to UVR and consequently their vulnerability to infection by S. ferax. Specifically, Kiesecker et al. [113] linked El Niño/Southern Oscillation events with decreased winter precipitation in the Oregon Cascade Range, and suggested that less winter snow pack resulted in lower water levels when $A$. boreas breed in early spring.

In contrast to the negative synergistic interaction found for UVR and S. ferax, studies examining the independent and interactive effects of UVR and Bd show either no interaction or an antagonistic interaction. Garcia et al. [154] examined the independent and interactive effects of UVR and Bd on metamorph survival of $R$. cascadae, A. boreas, and Pacific tree frog Pseudacris regilla, and while they found a significant increase in $\mathrm{Bd}$ induced mortality in $R$. cascadae and A. boreas, UVR exposure did not affect the survival of any species, and there was no interaction between the two factors. Similarly, Searle et al. [155] examined the independent and interactive effects of UVR and $\mathrm{Bd}$ on $R$. cascadae tadpoles and found that UVR exposure reduced survival, but there was no effect of Bd exposure, and no interaction between the two factors. Ortiz-Santaliestra et al. [156], on the other hand, found that UVR and Bd interacted antagonistically with the prevalence of Bd being significantly lower in common toad Bufo bufo tadpoles exposed to ambient UVR compared to those not exposed to UVR. Comparable to this finding by OrtizSantaliestra et al. [156], Walker et al. [157] found that conditional $\mathrm{Bd}$ prevalence (i.e. the prevalence of $\mathrm{Bd}$ infection conditioned on the probability of a site being infected) across the Iberian Peninsula was inversely correlated with UVR intensity for European midwife toad Alytes obstetricans. Thus while it has been hypothesised that increased UVR may make amphibians more susceptible to disease by causing immunosuppression, in the case of Bd infection, UVR exposure may benefit amphibians. The mechanism for this negative association between UVR exposure and Bd prevalence found by Ortiz-Santaliestra et al. [156] and Walker et al. [157] is unknown, but Ortiz-Santaliestra et al. [156] suggested that UVR exposure may either kill Bd directly, inhibit its development, or make it less virulent. Alternatively, the response of the host to UVR may negatively affect Bd prevalence. For example, changes in host activity caused by UVR exposure may reduce encounters with infected hosts, or UVR exposure may stimulate the production of antimicrobial peptides that may protect against Bd infection [156]. 
Further research is clearly needed with regard to the role of increased environmental UVR in the proliferation of diseases, particularly Bd, among amphibian populations. While current evidence supports the hypothesis that $\mathrm{Bd}$ is a novel pathogen [158], the hypothesis that human-induced environmental change may facilitate the $\mathrm{Bd}$ epidemic should continue to be explored. Although current research suggests that simultaneous exposure to UVR and Bd do not lead to synergistic effects, the finding of Ceccato et al. [68] suggests that exposure to UVR prior to metamorphosis may increase the susceptibility of amphibians to Bd following metamorphosis. Given that UVR exposure is more likely to afflict embryos and tadpoles, and that amphibians are more vulnerable to $\mathrm{Bd}$ following metamorphosis, the hypothesis proposed by Ceccato et al. [68] is an exciting avenue for future research.

\section{Conspecific density}

High conspecific density is a natural stressor that is likely to arise in amphibian habitats that are ephemeral. Ephemeral habitats are highly dynamic ecosystems often subjected to harsh and fluctuating conditions due to shallow water depths and high rates of evaporation [159-161]. Under these conditions, animal density increases as pond size decreases over time [159, 162]. High conspecific density is known to increase competition for resources and reduce rates of growth, rates of development, survival, and size at metamorphosis in amphibians $[61,163-167]$. In the only study to examine the interaction between UVR and conspecific density, Mitchell et al. [168] found that the interactive effects of UVR combined with high conspecific density varied with the response variable measured in embryos and tadpoles of the striped marsh frog Limnodynastes peronii. Both UVR and high conspecific density in isolation delayed the time to hatching of embryos, but in combination they interacted synergistically to further prolong the time to hatching. For the response variable of locomotor performance, only exposure to UVR had a negative effect and no interactive effect was observed. Interestingly, Mitchell et al. [168] found that while both high UVR and high conspecific density reduced tadpole size, the negative effect of UVR on tadpole size at low density was mitigated at high density indicating an antagonistic interaction. This finding suggests that when resources are not limiting, tadpoles living at higher densities may have more energy available for UVR defences because, unlike tadpoles living at lower densities, they allocate less energy to growth [168]. Consequently, amphibian species that develop at low densities, such as those in decline, may be particularly susceptible to the detrimental effects of increased environmental UVBR and may be driven towards extinction faster than what might be predicted from single-factor studies [168]. The study by Mitchell et al. [168] is a good example of how the interpretation of interactive effects varies depending on the response variable considered. Thus in order to determine how multiple factors might be contributing to amphibian declines, researchers need to be aware of how different response variables contribute towards individual fitness (i.e. the ability of individuals to survive and reproduce).

\section{Predation}

Predator-prey interactions are one of the most critical and significant interactions among organisms, having the potential to shape the behaviour, ecology and evolution of species [169]. The most obvious way in which predators impact upon prey is by killing and consuming them. However, predators can also impact upon prey through non-consumptive mechanisms that cause phenotypic changes in life-history traits, locomotor (escape) performance, behaviour, and morphology. Predators can also induce the stress response in their prey, which has consequences for their metabolism, digestive efficiency, growth, reproduction and immune function [170]. Amphibians exhibit a great variety of predatorinduced responses that improve their chances of survival in a predator environment including earlier hatching time of embryos [171], faster locomotory escape responses [66, 172], changed habitat use e.g. [173], reduced activity levels [174], and increased tail height of tadpoles [60, 175].

UVR exposure may increase the risk of predation for amphibians via several different pathways. One is by delaying the hatching time of embryos [168], which may increase their risk of predation by preventing them from hatching earlier to seek refuge. Another is by reducing the escape swimming speed of tadpoles $[65,168]$, which may increase their chances of being captured by a predator. Alton et al. [66] found that a faster escape swimming speed induced by exposure to water-borne predatory chemical cues improved the survival time of striped marsh frog Limnodynastes peronii tadpoles in an environment with predatory shrimp, which supports the hypothesis that escape swimming speed is important for tadpole survival in a predator environment. However unlike other studies, Alton et al. [66] found that exposure to a $3-6 \%$ increase in UVBR did not affect the escape swimming speed of tadpoles. Despite this, the survival time of tadpoles in an environment with predatory shrimp was reduced by $22-28 \%$ indicating that UVR may interfere with predator-prey interactions by impacting on other traits beside escape swimming speed.

Other anti-predator traits that may be affected by UVR exposure are behaviour and morphology. Garcia et al. [80] found that tadpoles of the streamside salamander 
Ambystoma barbouri responded to predatory fish by using spatial avoidance and retreating to shallower water. However, when simultaneously exposed to UVR, tadpoles preferred to spend more time in deeper, riskier water with predatory fish rather than face greater UVR exposure in shallower water. Similarly, Kats et al. [64] found that juveniles of the boreal toad Anaxyrus boreas exhibited avoidance behaviours in response to chemical cues from injured conspecifics and heterospecifics, but prior exposure to UVR suppressed this response. In a separate experiment, Kats et al. [64] found that tadpoles of the Cascades frog Rana cascadae reduced their activity levels when exposed to chemical cues from predatory newts, but again, prior exposure to UVR suppressed this anti-predator response. Alton et al. [62] investigated the effect of UVR on predator-induced morphological defences in $L$. peronii tadpoles and found that tadpoles exposed simultaneously to UVR and predatory chemical cues did not increase their tail height like those exposed only to predatory chemical cues. Such research demonstrates that UVR exposure may increase the risk of amphibians to predation by forcing them into habitats that they may otherwise avoid and suppressing the induction of anti-predator behavioural and morphological defences.

In addition to the interactive effects of UVR and predatory chemical cues that have been found on behavioural and morphological defences, Alton et al. [62] found that exposure to UVR in the presence of predatory chemical cues almost doubled the mortality of $L$. peronii tadpoles relative to that caused by UVR alone. Predatory chemical cues on their own had no affect on tadpole survival, and thus it is curious that they enhanced the mortality caused by UVR. Alton et al. [37] hypothesised that this synergistic effect of UVR and predatory chemical cues may be due to the energetic costs associated with being exposed to these two environmental factors. To test this hypothesis, Alton et al. [37] measured the tissue and whole-animal metabolic rate (the rate of oxygen consumption) and activity level of $L$. peronii tadpoles exposed to UVR and predatory chemical cues in isolation and in combination. UVR exposure increased tissue metabolic rate by $36 \%$ relative to unexposed tadpoles, which supports the hypothesis that exposure to UVR is energetically costly. However, at the whole-animal level, UVR exposure caused tadpoles to reduce their metabolic rate by $14 \%$ and activity level by $56 \%$. This suggests that by expending less energy on locomotion, tadpoles ultimately over compensated for the added maintenance costs associated with defending against UVR-induced damage. Predatory chemical cues, on the other hand, did not affect tissue or whole-animal metabolic rate, but caused tadpoles to reduce their activity levels by $36 \%$. This finding suggests that the threat of predation elevated tadpole metabolism, possibly via the stress response, but as with UVR exposure, tadpoles were able to compensate for this by reducing the energy they expended on locomotion. Similarly, the threat of predation combined with UVR exposure resulted in no net change in tadpole metabolism despite these tadpoles showing the largest reduction in activity level of all treatment groups (a $62 \%$ reduction). Given that in the absence of predatory chemical cues tadpoles exposed to UVR were able to reduce their metabolism with less of a reduction in activity, it seems likely that exposure to both factors in combination is more energetically costly than being exposed to either factor in isolation. This finding may explain why tadpoles exposed to both factors simultaneously suffered greater mortality, and also provides a mechanistic basis for other interactive effects between other environmental factors.

\section{Conclusions}

The realisation that human activities were destroying stratospheric ozone and increasing the amount of damaging UVBR reaching the biosphere sparked considerable interest in the effects of UVR on living organisms. For amphibians specifically, this interest has increased our appreciation for the potential role of UVR in shaping amphibian populations. UVBR exposure can increase the mortality of embryos and tadpoles and cause various sublethal effects that may either reduce their chances of survival through to metamorphosis, or carry over to life stages beyond metamorphosis.

UVR exposure has been an important selective pressure for amphibians that has led to the evolution of defence mechanisms that either prevent UVR damage from occurring, or repair UVR damage once it has occurred. The sensitivity of amphibians to UVR varies among species and populations and this is associated with variation in the strategies they employ to defend against UVR damage. We therefore encourage future research to further explore the associations between environmental UVR protection and behavioural and physiological UVR defences for amphibians. Associated with this is the need for an improved understanding of the ability of amphibians to behaviourally and physiologically acclimatise and adapt to changes in environmental UVR. Such research will be important for: (a) identifying amphibian species that may be particularly vulnerable to UVR; and (b) assessing the threat of future changes in UVR to amphibians, especially for those species in the tropics where UVR exposure is predicted to increase.

As research has shifted from examining the effects of environmental factors in isolation towards exploring the effects of multiple environmental factors in combination, we now know that examining the effects of UVR in the 
absence of other ecologically relevant environmental factors (e.g. temperature, hypoxia, aquatic $\mathrm{pH}$, disease, conspecific density, and predation) can greatly oversimplify and underestimate the effects of UVR on amphibians. The present synthesis highlights that the interactive effects between UVR and other environmental factors arise via several complex pathways that are likely to be mediated by the behavioural and physiological responses of amphibians to each of the environmental factors in isolation. Therefore, controlled laboratory-based, multifactorial experimental studies will remain useful for testing hypotheses about how interactive effects emerge, particularly those related to immune function and disease susceptibility. However, understanding the effects of UVR in the context of the natural environment (i.e. in the field) as opposed to the laboratory will be critical for assessing the relative contribution of changes in UVR to shaping amphibian populations. The implications of interactive effects for amphibian population persistence could be examined by exposing populations within outdoor mesocosms to manipulated experimental conditions across multiple generations and measuring the remaining number of individuals within each population to determine whether they have declined, increased, or remained stable.

Now that stratospheric ozone levels have stabilised due the success of the Montreal Protocol in phasing out ozone-depleting substances, the effect of greenhouse gas emissions on ozone recovery presents new challenges for predicting future UVR levels. Changes in UVR will also be associated with changes in other factors such as temperature, vegetative cover, precipitation, ice and snow cover, aquatic $\mathrm{pH}$ and dissolved organic carbon $[11,176]$. Consequently, although the threat from ozone-depleting substances has abated, we cannot afford to slow our progress on understanding the effects of UVR on living organisms, including amphibians. In particular, we must improve our understanding of how UVR interacts with other environmental factors, including those that are naturally occurring as well as those that are changing as a consequence of human activity. A sound understanding of the pathways that give rise to independent and interactive effects of multiple environmental factors at the cellular and organismal level will provide the foundation for a strong theoretical framework that will allow researchers to make predictions regarding the environmental factors and specific conditions necessary to induce changes in abundance at the population level. Once an understanding is formed of the role of particular factors in amphibian declines, researchers can then begin to investigate the potential for individuals to acclimate and ultimately adapt to future environmental conditions, which will be important for understanding species' persistence.

\section{Abbreviations}

6-4PP: (6-4) pyrimidine-pyrimidone; 8-oxoGua: 8-oxo-7,8-dihydroguanine; CPD: Cyclobutane pyrimidine dimer; DOC: Dissolved organic carbon; GHG: Greenhouse gas; ODS: Ozone-depleting substance; ROS: Reactive oxygen species; UVAR: Ultraviolet-A radiation; UVBR: Ultraviolet-B radiation; UVR: Ultraviolet radiation

\section{Acknowledgements}

We would like to thank Andrew Blaustein and two anonymous referees for providing comments that improved the manuscript. We would also like to thank Elia Pirtle for producing Fig. 2.

Funding

Not applicable.

Availability of data and materials

Not applicable.

Authors' contributions

All authors conceived of the review and contributed to drafting the manuscript. Both authors read and approved the final manuscript.

Ethics approval and consent to participate

Not applicable.

Consent for publication

Not applicable.

\section{Competing interests}

The authors declare that they have no competing interests.

\section{Publisher's Note}

Springer Nature remains neutral with regard to jurisdictional claims in published maps and institutional affiliations.

Received: 2 May 2017 Accepted: 22 September 2017

Published online: 09 November 2017

\section{References}

1. International Union for Conservation of Nature. The IUCN Red List of Threatened Species. Version 2016-2. 2016. http://www.iucnredlist.org. Accessed 16 November 2016.

2. Stuart SN, Hoffmann M, Chanson JS, Cox NA, Berridge RJ, Ramani P, Young $\mathrm{BE}$, editors. Threatened Amphibians of the World. Barcelona: Lynx Edicions; 2008.

3. Stuart SN, Chanson JS, Cox NA, Young BE, Rodrigues ASL, Fischman DL, Waller RW. Status and trends of amphibian declines and extinctions worldwide. Science. 2004;306:1783-6.

4. Stebbins RC, Cohen NW. A natural history of amphibians. Princeton: Princeton University Press; 1995.

5. Whiles MR, Lips KR, Pringle CM, Kilham SS, Bixby RJ, Brenes R, Connelly S, Colon-Guad JC, Hunte-Brown M, Huryn AD, Montgomery C, Peterson S. The effects of amphibian population declines on the structure and function of Neotropical stream ecosystems. Front Ecol Environ. 2006;4:27-34.

6. Collins JP, Crump ML. Extinction In Our Times: Global Amphibian Decline. New York: Oxford University Press; 2009.

7. Blaustein AR, Han BA, Relyea RA, Johnson PT, Buck JC, Gervasi SS, Kats LB. The complexity of amphibian population declines: understanding the role of cofactors in driving amphibian losses. Ann N Y Acad Sci. 2011;1223:108-19.

8. Blaustein AR, Kiesecker JM. Complexity in conservation: lessons from the global decline of amphibian populations. Ecol Lett. 2002;5:597-608.

9. Farman JC, Gardiner BG, Shanklin JD. Large losses of total ozone in Antarctica reveal seasonal $\mathrm{ClO}_{x} / \mathrm{NO}_{x}$ interaction. Nature. 1985;315:207-10.

10. Xenopoulos MA, Schindler DW. Physical factors determining ultraviolet radiation flux into ecosystems. In: Cockell CS, Blaustein AR, editors. Ecosystems, Evolution, and Ultraviolet Radiation. New York: Springer-Verlag; 2001. p. 36-62.

11. Croteau MC, Davidson MA, Lean DRS, Trudeau VL. Global increases in ultraviolet $B$ radiation: potential impacts on amphibian development and metamorphosis. Physiol Biochem Zool. 2008;81:743-61. 
12. Webb AR. Ozone depletion and changes in environmental UV-B radiation. In: Hester RE, Harrison RM, editors. Causes and Environmental Implications of Increased UV-B Radiation. Cambridge: The Royal Society of Chemistry; 2000. p. 17-36.

13. World Meteorological Organization. Scientific Assessment of Ozone Depletion: 2010, Global Ozone Research and Monitoring Project - Report No. 52. Geneva: World Meteorological Organization; 2011.

14. World Meteorological Organization. Scientific Assessment of Ozone Depletion: 2014, Global Ozone Research and Monitoring Project - Report No. 55. Geneva: World Meteorological Organization; 2014.

15. World Meteorological Organization. Scientific Assessment of Ozone Depletion: 2006, Global Ozone Research and Monitoring Project - Report No. 50. Geneva: World Meteorological Organization; 2007.

16. Herman JR. Global increase in UV irradiance during the past 30 years (19792008) estimated from satellite data. J Geophys Res. 2010;115:D04203.

17. Middleton EM, Herman JR, Celarier EA, Wilkinson JW, Carey C, Rusin RJ. Evaluating ultraviolet radiation exposure with satellite data at sites of amphibian declines in Central and South America. Conserv Biol. 2001;15:914-29.

18. Setlow RB. The wavelengths in sunlight effective in producing skin cancer: a theoretical analysis. Proc Natl Acad Sci U S A. 1974;71:3363-6.

19. McKinlay AF, Diffey BL. A reference action spectrum for ultraviolet-induced erythema in skin. In: Passchier WF, Bosnjakovic BFM, editors. Human Exposure to Ultraviolet Radiation: Risks and Regulations. Amsterdam: Elsevier; 1987. p. 83-7.

20. McKenzie RL, Aucamp PJ, Bais AF, Bjorn LO, llyas M, Madronich S. Ozone depletion and climate change: impacts on UV radiation. Photochem Photobiol Sci. 2011;10:182-98.

21. Friedberg EC, Walker GC, Siede W, Wood RD, Schultz RA, Ellenberger T. DNA Repair and Mutagenesis. 2nd ed. Washington DC: ASM Press; 2006.

22. Cadet J, Douki T, Ravanat JL. Oxidatively generated damage to cellular DNA by UVB and UVA radiation. Photochem Photobiol. 2015;91:140-55.

23. Niki E. Lipid peroxidation. In: Chryssostomos C, Studer A, editors. Encyclopedia of Radicals in Chemistry, Biology and Materials. Hoboken: Wiley; 2012.

24. Davies MJ. Oxidative damage to proteins. In: Chatgilialoglu C, Studer A, editors. Encyclopedia of Radicals in Chemistry, Biology and Materials. Hoboken: Wiley; 2012.

25. de Gruijl FR, van Kranen HJ, Mullenders LHF. UV-induced DNA damage, repair, mutations and oncogenic pathways in skin cancer. J Photochem Photobiol B. 2001;63:19-27.

26. Cockell CS, Knowland J. Ultraviolet radiation screening compounds. Biol Rev. 1999;74:311-45.

27. Jantschitsch C, Trautinger F. Heat shock and UV-B-induced DNA damage and mutagenesis in skin. Photochem Photobiol Sci. 2003;2:899-903.

28. Sancar A. Structure and function of DNA photolyase and cryptochrom bluelight photoreceptors. Chem Rev. 2003;103:2203-37.

29. Teoh CY, Davies KJA. Oxidative defense mechanisms. In: Cutler RG, Rodriguez $\mathrm{H}$, editors. Critical Reviews of Oxidative Stress and Aging: Advances in Basic Sciences, Diagnostics and Intervention. Singapore: World Scientific Publishing; 2003. p. 679-89.

30. Karentz D, Bothwell ML, Coffin RB, Hanson A, Herndl GJ, Kilham SS, Lesser MP, Lindell M, Moeller RE, Morris DP, Neale PJ, Sanders RW, Weiler CS, Wetzel RG. Impact of UV-B radiation on pelagic freshwater ecosystems: report of working group on bacteria and phytoplankton. Archiv für Hydrobiologie Beiheft Ergebnisse der Limnologie. 1994;43:31-69.

31. Häder D-P, Kumar HD, Smith RC, Worrest RC. Aquatic ecosystems: effects of solar ultraviolet radiation and interactions with other climatic change factors. Photochem Photobiol Sci. 2003;2:39-50.

32. Caldwell MM, Björn LO, Bornman JF, Flint SD, Kulandaivelu G, Teramura AH, Tevini M. Effects of increased solar ultraviolet radiation on terrestrial ecosystems. J Photochem Photobiol B Biol. 1998;46:40-52.

33. Hessen DO. UVR and pelagic metazoans. In: Helbling ER, Zagarese $H$, editors. UV Effects in Aquatic Organisms and Ecosystems. Cambridge: Royal Society of Chemistry; 2003. p. 401-30.

34. Dahms H-U, Lee J-S. UV radiation in marine ectotherms: molecular effects and responses. Aquat Toxicol. 2010;97:3-14.

35. Tevini M, editor. UV-B Radiation and Ozone Depletion: Effects on Humans, Animals, Plants, Microorganisms, and Materials. Boca Raton: Lewis Publishers; 1993.

36. Lesser MP, Kruse VA, Barry TM. Exposure to ultraviolet radiation causes apoptosis in developing sea urchin embryos. J Exp Biol. 2003;206:4097-103.
37. Alton LA, White CR, Wilson RS, Franklin CE. The energetic cost of exposure to UV radiation for tadpoles is greater when they live with predators. Funct Ecol. 2012;26:94-103.

38. Fischer JM, Fields PA, Pryzbylkowski PG, Nicolai JL, Neale PJ. Sublethal exposure to UV radiation affects respiration rates of the freshwater cladoceran Daphnia catawba. Photochem Photobiol. 2006:82:547-50.

39. Kazerouni EG, Franklin CE, Seebacher F. UV-B radiation interacts with temperature to determine animal performance. Funct Ecol. 2016;30:584-95.

40. Snell KRS, Kokubun T, Griffiths H, Convey P, Hodgson DA, Newsham KK. Quantifying the metabolic cost to an Antarctic liverwort of responding to an abrupt increase in UVB radiation exposure. Glob Chang Biol. 2009;15: 2563-73.

41. Jokinen El, Salo HM, Markkula SE, Aaltonen TM, Immonen AK. Effects of ultraviolet light on immune parameters of the roach. Toxicol Lett. 2000; 112(113):303-10.

42. Belden LK, Moore IT, Mason RT, Wingfield JC, Blaustein AR. Survival, the hormonal stress response and UV-B avoidance in Cascades Frog tadpoles (Rana cascadae) exposed to UV-B radiation. Funct Ecol. 2003;17:409-16.

43. Wendelaar Bonga SE. The stress response in fish. Physiol Rev. 1997;77:591-625.

44. Elmets CA, Cala CM, Xu H. Photoimmunology. Dermatol Clin. 2014;32: 277-90.

45. Blaustein AR, Bancroft BA. Amphibian population declines: evolutionary considerations. Bioscience. 2007:57:437-44.

46. Hoff KvS, Blaustein AR, McDiarmid RW, Altig R. Behavior: interactions and their consequences. In: McDiarmid RW, Altig R, editors. Tadpoles: The Biology of Anuran Larvae. Chicago: University of Chicago Press; 1999. p. 215-39.

47. Ultsch GR, Bradford DF, Freda J. Physiology: coping with the environment. In: McDiarmid RW, Altig R, editors. Tadpoles: The Biology of Anuran Larvae. Chicago: University of Chicago Press; 1999. p. 189-214.

48. Benard MF. Predator-induced phenotypic plasticity in organisms with complex life histories. Annu Rev Ecol Evol Syst. 2004:35:651-73.

49. Bradford DF. Temperature modulation in a high-elevation amphibian, Rana muscosa. Copeia. 1984;1984:966-76.

50. Han BA, Kats LB, Pommerening RC, Ferrer RP, Murry-Ewers M, Blaustein AR. Behavioral avoidance of ultraviolet-B radiation by two species of neotropical poison-dart frogs. Biotropica. 2007;39:433-5.

51. Blaustein AR, Belden LK. Amphibian defenses against ultraviolet-B radiation. Evol Dev. 2003;5:89-97.

52. Blaustein AR, Belden LK, Hatch AC, Kats LB, Hoffman PD, Hays JB, Marco A Chivers DP, Kiesecker JM. Ultraviolet radiation and amphibians. In: Cockell CS, Blaustein AR, editors. Ecosystems, Evolution, and Ultraviolet Radiation. Berlin: Springer-Verlag; 2001. p. 63-79.

53. Blaustein AR, Kiesecker JM, Chivers DP, Hokit DG, Marco A, Belden LK, Hatch A. Effects of ultraviolet radiation on amphibians: field experiments. Am Zool. 1998:38:799-812.

54. Blaustein AR, Romansic JM, Kiesecker JM, Hatch AC. Ultraviolet radiation, toxic chemicals and amphibian population declines. Divers Distrib. 2003;9: 123-40.

55. Bancroft BA, Baker NJ, Blaustein AR. A meta-analysis of the effects of ultraviolet $\mathrm{B}$ radiation and its synergistic interactions with $\mathrm{pH}$, contaminants, and disease on amphibian survival. Conserv Biol. 2008;22:987-96.

56. Hayes TB, Falso P, Gallipeau S, Stice M. The cause of global amphibian declines: a developmental endocrinologist's perspective. J Exp Biol. 2010; 213:921-33.

57. Vonesh JR, De la Cruz O. Complex life cycles and density dependence: assessing the contribution of egg mortality to amphibian declines. Oecologia. 2002;133:325-33.

58. Croteau MC, Martyniuk CJ, Trudeau VL, Lean DRS. Chronic exposure of Rana pipiens tadpoles to UVB radiation and the estrogenic chemical 4-tertoctylphenol. J Toxicol Environ Health, Part A. 2008;71:134-44.

59. Walker JA, Ghalambor CK, Griset OL, McKenney D, Reznick DN. Do faster starts increase the probability of evading predators? Funct Ecol. 2005;19: 808-15.

60. McCollum SA, Van Buskirk J. Costs and benefits of a predator-induced polyphenism in the gray treefrog Hyla chrysoscelis. Evolution. 1996;50: 583-93.

61. Berven KA. Factors affecting population fluctuations in larval and adult stages of the wood frog (Rana sylvatica). Ecology. 1990;71:1599-608.

62. Alton LA, Wilson RS, Franklin CE. Risk of predation enhances the lethal effects of UV-B in amphibians. Glob Chang Biol. 2010;16:538-45. 
63. Pahkala M, Laurila A, Merilä J. Carry-over effects of ultraviolet-B radiation on larval fitness in Rana temporaria. Proc R Soc Lond B. 2001;268:1699-706.

64. Kats LB, Kiesecker JM, Chivers DP, Blaustein AR. Effects of UV-B on antipredator behavior in three species of amphibians. Ethology. 2000;106: 921-32.

65. van Uitregt VO, Wilson RS, Franklin CE. Cooler temperatures increase sensitivity to ultraviolet $B$ radiation in embryos and larvae of the frog Limnodynastes peronii. Glob Chang Biol. 2007;13:1114-21.

66. Alton LA, Wilson RS, Franklin CE. A small increase in UV-B increases the susceptibility of tadpoles to predation. Proc R Soc Lond B. 2011;278: 2575-83.

67. Romansic JM, Waggener AA, Bancroft BA, Blaustein AR. Influence of ultraviolet-B radiation on growth, prevalence of deformities, and susceptibility to predation in Cascades frog (Rana cascadae) larvae. Hydrobiologia. 2009;624:219-33.

68. Ceccato E, Cramp RL, Seebacher F, Franklin CE. Early exposure to ultraviolet$\mathrm{B}$ radiation decreases immune function later in life. Cons Physiol. 2016:4: cow037.

69. Schuch AP, Santos MB, Lipinski VM, Peres LV, Santos CP, Cechin SZ, Schuch NJ, Pinheiro DK, Loreto ELS. Identification of influential events concerning the Antarctic ozone hole over southern Brazil and the biological effects induced by UVB and UVA radiation in an endemic treefrog species. Ecotoxicol Environ Saf. 2015;118:190-8.

70. Herkovits J. D'Eramo jL, Fridman O. The effect of UV-B radiation on Bufo arenarum embryos survival and superoxide dismutase activity. Int J Environ Res Public Health. 2006;3:43-7.

71. Lesser MP, Turtle SL, Farrell JH, Walker CW. Exposure to ultraviolet radiation (290-400 nm) causes oxidative stress, DNA damage, and expression of p53/ p73 in laboratory experiments on embryos of the spotted salamander, Ambystoma maculatum. Physiol Biochem Zool. 2001;74:733-41.

72. Kern P, Cramp RL, Seebacher F, Kazerouni EG, Franklin CE. Plasticity of protective mechanisms only partially explain interactive effects of temperature and UVR on upper thermal limits. Comp Biochem Physiol A. 2015;190:75-82.

73. Diamond SA, Peterson GS, Tietge JE, Ankley GT. Assessment of the risk of solar ultraviolet radiation to amphibians. III. Prediction of impacts in selected northern midwestern wetlands. Environ Sci Technol. 2002;36:2866-74.

74. Palen WJ, Schindler DE. Water clarity, maternal behavior, and physiology combine to eliminate UV radiation risk to amphibians in a montane landscape. Proc Natl Acad Sci U S A. 2010;107:9701-6.

75. Olker JH, Johnson LB, Axler RP, Johnson CM, Smith R. Factors influencing ultraviolet radiation dose to developing frogs in northern vernal pools. Can J Fish Aquat Sci. 2013;70:1531-41.

76. Palen WJ, Williamson CE, Clauser AA, Schindler DE. Impact of UV-B exposure on amphibian embryos: linking species physiology and oviposition behaviour. Proc R Soc Lond B. 2005;272:1227-34.

77. Thurman LL, Garcia TS, Hoffman PD. Elevational differences in trait response to UV-B radiation by long-toed salamander populations. Oecologia. 2014; 175:835-45.

78. Belden LK, Wildy EL, Blaustein AR. Growth, survival and behaviour of larval long-toed salamanders (Ambystoma macrodactylum) exposed to ambient levels of UV-B radiation. J Zool. 2000;251:473-9.

79. Connolly JC, Kress BL, Smith GR, Rettig JE. Possible behavioral avoidance of UV-B radiation and sunlight in wood frrog (Lithobates sylvaticus) tadpoles. Curr Herpetol. 2011;30:1-5.

80. Garcia TS, Stacy J, Sih A. Larval salamander response to UV radiation and predation risk: color change and microhabitat use. Ecol Appl. 2004; 14:1055-64.

81. Nagl AM, Hofer R. Effects of ultraviolet radiation on early larval stages of the Alpine newt, Triturus alpestris, under natural and laboratory conditions. Oecologia. 1997;110:514-9.

82. Bancroft BA, Baker NJ, Searle CL, Garcia TS, Blaustein AR. Larval amphibians seek warm temperatures and do not avoid harmful UVB radiation. Behav Ecol. 2008;19:879-86.

83. Sih A, Ferrari MCO, Harris DJ. Evolution and behavioural responses to human-induced rapid environmental change. Evol Appl. 2011;4:367-87.

84. Hofer R, Mokri C. Photoprotection in tadpoles of the common frog, Rana temporaria. J Photochem Photobiol B. 2000:59:48-53.

85. Cummins CP, Greenslade PD, McLeod AR. A test of the effect of supplemental UV-B radiation on the common frog, Rana temporaria L., during embryonic development. Glob Chang Biol. 1999;5:471-9.
86. Belden LK, Blaustein AR. UV-B induced skin darkening in larval salamanders does not prevent sublethal effects of exposure on growth. Copeia. 2002; 2002:748-54.

87. Garcia TS, Paoletti DJ, Blaustein AR. Correlated trait responses to multiple selection pressures in larval amphibians reveal conflict avoidance strategies. Freshw Biol. 2009;54:1066-77.

88. Garcia TS, Paoletti DJ, Blaustein AR. Correlated trait response: comparing amphibian defense strategies across a stress gradient. Can J Zool. 2009;87:41-9.

89. Langhelle A, Lindell MJ, Nyström P. Effects of ultraviolet radiation on amphibian embryonic and larval development. J Herpetol. 1999;33:449-56.

90. Zaga A, Little EE, Rabeni CF, Ellersieck MR. Photoenhanced toxicity of a carbamate insecticide to early life stage anuran amphibians. Environ Toxicol Chem. 1998:17:2543-53.

91. Ali SA, Salim S, Ali AS, Peter J. In-vitro analysis on the effects of UV-B radiation on the dorsal skin melanophores of Indian bullfrog Hoplobatrachus tigerinus. Int J Pharma Bio Sci. 2011;2:158-73.

92. Perotti MG, Diéguez MC. Effect of UV-B exposure on eggs and embryos of patagonian anurans and evidence of photoprotection. Chemosphere. 2006; 65:2063-70.

93. Grant KP, Licht LE. Effects of UV radiation on life history stages of anurans from Ontario Canada. Can J Zool. 1995:73:2292-301.

94. Hansen $L$, Fabacher DL, Calfee R. The role of the egg jelly coat in protecting Hyla regilla and Bufo canorus embryos from ultraviolet-B radiation during development. Environ Sci Pollut Res. 2002;9:412-6.

95. Licht LE. Shedding light on ultraviolet radiation and amphibian embryos. Bioscience. 2003:53:551-61.

96. Ovaska K, Davis TM, Flamarique IN. Hatching success and survival of frogs Hyla regilla and Rana aurora under ambient and artificially enhanced solar ultraviolet radiation. Can J Zool. 1997;75:1081-8.

97. Smith MA, Berrill M, Kapron CM. Photolyase activity of the embryo and the ultraviolet absorbance of embryo jelly for several Ontario amphibian species. Can J Zool. 2002:80:1109-16.

98. Marquis O, Miaud C, Lena J-P. Developmental responses to UV-B radiation in common frog Rana temporaria embryos from along an altitudinal gradient. Popul Ecol. 2008;50:123-30.

99. Blaustein AR, Hays JB, Hoffman PD, Chivers DP, Kiesecker JM, Leonard WP, Marco A, Olson DH, Reaser JK, Anthony RG. DNA repair and resistance to UV-B radiation in western spotted frogs. Ecol Appl. 1999:9:1100-5.

100. Blaustein AR, Hoffman PD, Hokit DG, Kiesecker JM, Walls SC, Hays JB. UV repair and resistance to solar UV-B in amphibian eggs: a link to population declines? Proc Natl Acad Sci U S A. 1994;91:1791-5.

101. Blaustein AR, Hoffman PD, Kiesecker JM, Hays JB. DNA repair activity and resistance to solar UV-B radiation in eggs of the red-legged frog. Conserv Biol. 1996;10:1398-402.

102. Hays JB, Blaustein AR, Kiesecker JM, Hoffman PD, Pandelova I, Coyle D, Richardson T. Developmental response to amphibians to solar and artificial UVB sources: A comparative study. Photochem Photobiol. 1996;64:449-56.

103. van de Mortel T, Buttemer W, Hoffman P, Hays J, Blaustein A. A comparison of photolyase activity in three Australian tree frogs. Oecologia. 1998;115: 366-9.

104. Huey RB, Hertz PE, Sinervo B. Behavioural drive versus behavioural inertia in evolution: a null hypothesis approach. Am Nat. 2003;161:357-66.

105. Linder G, Krest SK, Sparling DW, editors. Amphibian Decline: An Integrated Analysis of Multiple Stressor Effects. Pensacola: Society of Environmental Toxicology and Chemistry; 2003.

106. Wake DB, Vredenburg VT. Are we in the midst of the sixth mass extinction? A view from the world of amphibians. Proc Natl Acad Sci U S A. 2008;105: 11466-73.

107. Collins JP, Storfer A. Global amphibian declines: sorting the hypotheses. Divers Distrib. 2003:9:89-98.

108. Storfer A. Amphibian declines: future directions. Divers Distrib. 2003;9:151-63.

109. Folt CL, Chen CY, Moore MV, Burnaford J. Synergism and antagonism among multiple stressors. Limnol Oceanogr. 1999;44:864-77.

110. Huey RB, Stevenson RD. Integrating thermal physiology and ecology of ecotherms: a discussion of approaches. Am Zool. 1979;19:357-66.

111. Blaustein AR, Romansic JM, Scheessele EA. Ambient levels of ultraviolet-B radiation cause mortality in juvenile western toads, Bufo Boreas. Am Midl Nat. 2005:154:375-82.

112. Kiesecker JM, Blaustein AR. Synergism between UV-B radiation and a pathogen magnifies amphibian embryo mortality in nature. Proc Natl Acad Sci U S A. 1995;92:11049-52. 
113. Kiesecker JM, Blaustein AR, Belden LK. Complex causes of amphibian population declines. Nature. 2001;410:681-4.

114. Broomhall SD, Osborne WS, Cunningham RB. Comparative effects of ambient ultraviolet-B radiation on two sympatric species of Australian frogs. Conserv Biol. 2000;14:420-7.

115. Sanders RW, Macaluso AL, Sardina TJ, Mitchell DL. Photoreactivation in two freshwater ciliates: differential responses to variations in UV-B flux and temperature. Aquat Microb Ecol. 2005;40:283-92.

116. MacFadyen EJ, Williamson CE, Grad G, Lowery M, Jeffrey WH, Mitchell DL. Molecular response to climate change: temperature dependence of UVinduced DNA damage and repair in the freshwater crustacean Daphnia pulicaria. Glob Chang Biol. 2004;10:408-16.

117. Pakker H, Martins RST, Boelen P, Buma AGJ, Nikaido O, Breeman AM. Effects of temperature on the photoreactivation of ultraviolet-B-induced DNA damage in Palmaria palmata (Rhodophyta). J Phycol. 2000;36:334-41.

118. Li SS, Paulsson M, Björn LO. Temperature-dependent formation and photorepair of DNA damage induced by UV-B radiation in suspensioncultured tobacco cells. J Photochem Photobiol B. 2002;66:67-72.

119. Lamare MD, Barker MF, Lesser MP, Marshall C. DNA photorepair in echinoid embryos: effects of temperature on repair rate in Antarctic and nonAntarctic species. J Exp Biol. 2006;209:5017-28.

120. Connelly SJ, Moeller RE, Sanchez G, Mitchell DL. Temperature effects on survival and DNA repair in four freshwater cladoceran Daphnia species exposed to UV radiation. Photochem Photobiol. 2009;85:144-52.

121. Kern P, Cramp RL, Franklin CE. Temperature and UV-B-insensitive performance in tadpoles of the ornate burrowing frog: an ephemeral pond specialist. J Exp Biol. 2014;217:1246-52.

122. Niehaus AC, Angilletta MJ Jr, Sears MW, Franklin CE, Wilson RS. Predicting the physiological performance of ectotherms in fluctuating thermal environments. J Exp Biol. 2012;215:694-701.

123. Alton LA, Franklin CE. Do high temperatures enhance the negative effects of ultraviolet-B radiation in embryonic and larval amphibians? Biol Open. 2012;1:897-903.

124. Meyer EA. Acid adaptation and mechanisms for softwater acid tolerance in larvae of anuran species native to the 'Wallum' of east Australia. PhD. Brisbane: The University of Queensland; 2004.

125. Gosner $\mathrm{KL}$, Black IH. The effects of acidity on the development and hatching of New Jersey frogs. Ecology. 1957;38:256-62.

126. Aston RJ, Beattie RC, Milner AGP. Characteristics of spawning sites of the common frog (Rana temporaria) with particular reference to acidity. J Zool. 1987;213:233-42.

127. Dunson WA, Wyman RL, Corbett ES. A symposium on amphibian declines and habitat acidification. J Herpetol. 1992;26:349-52.

128. Pierce BA. Acid tolerance in amphibians. Bioscience. 1985;35:239-43.

129. Pierce BA. The effects of acid precipitation on amphibians. Ecotoxicology. 1993:2:65-77.

130. Meyer EA, Cramp RL, Franklin CE. Damage to the gills and integument of Litoria fallax larvae (Amphibia: Anura) associated with ionoregulatory disturbance at low pH. Comp Biochem Physiol A. 2010;155:164-71.

131. Freda J, Dunson WA. Sodium balance of amphibian larvae exposed to low environmental pH. Physiol Zool. 1984:57:435-43.

132. Wells KD. Ecology and Behavior of Amphibians. Chicago: The University of Chicago Press; 2007.

133. Fominykh AS. An experimental study on the effect of alkaline water $\mathrm{pH}$ on the dynamics of amphibian larval development. Russ J Ecol. 2008;39:145-7.

134. Long LE, Saylor LS, Soulé ME. A pH/UV-B synergism in amphibians. Conserv Biol. 1995;9:1301-3.

135. Pahkala M, Laurila A, Björn LO, Merilä J. Effects of ultraviolet-B radiation and $\mathrm{pH}$ on early development of the moor frog Rana arvalis. J Appl Ecol. 2001; 38:628-36.

136. Pahkala M, Laurila A, Merilä J. Ambient ultraviolet-B radiation reduces hatchling size in the common frog Rana temporaria. Ecography. 2000;23: 531-8.

137. Pahkala M, Räsänen K, Laurila A, Johanson U, Björn LO, Merilä J. Lethal and sublethal effects of UV-B/pH synergism on common frog embyros. Conserv Biol. 2002;16:1063-73.

138. Hassell KL, Coutin PC, Nugegoda D. A novel approach to controlling dissolved oxygen levels in laboratory experiments. J Exp Mar Biol Ecol. 2009; 371:147-54.

139. Werner EE, Blennemeier KS. Influence of canopy cover on the breeding pond distributions of several amphibian species. Copeia. 1999;1999:1-12.
140. Seymour RS, Roberts JD, Mitchell NJ, Blaylock AJ. Influence of environmental oxygen on development and hatching of aquatic eggs of the Australian frog. Crinia georgiana. Physiol Biochem Zool. 2000;73:501-7.

141. Seymour RS, Mahony MJ, Knowles R. Respiration of embryos and larvae of the terrestrially breeding frog Kyarranus loveridgei. Herpetologica. 1995;51: 369-76.

142. Seymour RS, Roberts JD. Embryonic respiration and oxygen distribution in foamy and nonfoamy egg masses of the frog Limnodynastes tasmaniensis. Physiol Zool. 1991;64:1322-40.

143. Burggren WW, Feder ME, Pinder AW. Temperature and the balance between aerial and aquatic respiration in larvae of Rana berlandieri and Rana catesbeiana. Physiol Zool. 1983;56:263-73.

144. Wong S, Booth DT. Hypoxia induces surfacing behavior in brownstriped frog (Limnodynastes peronii) larvae. Comp Biochem Physiol A. 1994;109:347-445.

145. Noland R, Ultsch GR. The roles of temperature and dissolved oxygen in microhabitat selection by the tadpoles of a frog (Rana pipiens) and a toad (Bufo terrestris). Copeia. 1981;1981:645-52.

146. Wassersug RJ, Seibert EA. Behavioral responses of amphiban larvae to variation in dissolved oxygen. Copeia. 1975;1975:87-103.

147. Bernal MH, Alton LA, Cramp RL, Franklin CE. Does simultaneous exposure UV-B exposure enhance the lethal and sub-lethal effects of aquatic hypoxia on developing anuran embryos and larvae? J Comp Physiol B. 2011;181: 973-80.

148. Daszak P, Cunningham AA, Hyatt AD. Infectious disease and amphibian population declines. Divers Distrib. 2003;9:141-50.

149. Skerratt LF, Berger L, Speare R, Cashins S, McDonald KR, Phillott AD, Hines $H B$, Kenyon N. Spread of chytridiomycosis has caused the rapid global decline and extinction of frogs. EcoHealth. 2007:4:125-34.

150. Rachowicz LJ, Hero J-M, Alford RA, Taylor JW, Morgan JAT, Vredenburg VT, Collins JP, Briggs CJ. The novel and endemic pathogen hypotheses: competing explanations for the origin of emerging infectious diseases of wildlife. Conserv Biol. 2005;19:1441-8.

151. Carey C, Cohen N, Rollins-Smith L. Amphibian declines: an immunological perspective. Dev Comp Immunol. 1999;23:459b472.

152. Schwarz T. Mechanisms of UV-induced immunosuppression. Keio J Med. 2005;54:165-71.

153. Goettsch W, Garssen J, de Klerk A, Herremans TMPT, Dortant P, de Gruijl FR, van Loveren $\mathrm{H}$. Effects of ultraviolet-B exposure on resistance to Listeria monocytogenes in the rat. Photochem Photobiol. 1996;63:672-9.

154. Garcia TS, Romansic JM, Blaustein AR. Survival of three species of anuran metamorphs exposed to UV-B radiation and the pathogenic fungus Batrachochytrium dendrobatidis. Dis Aquat Org. 2006;72:163-9.

155. Searle CL, Belden LK, Bancroft BA, Han BA, Biga LM, Blaustein AR. Experimental examination of the effects of ultraviolet- $B$ radiation in combination with other stressors on frog larvae. Oecologia. 2010;162: 237-45.

156. Ortiz-Santaliestra ME, Fisher MC, Fernández-Beaskoetxea S, FernándezBenéitez MJ, Bosch J. Ambient ultraviolet B radiation and prevalence of infection by Batrachochytrium dendrobatidis in two amphibian species. Conserv Biol. 2011:25:975-82.

157. Walker SF, Bosch J, Gomez V, Garner TW, Cunningham AA, Schmeller DS, Ninyerola M, Henk DA, Ginestet C, Arthur CP, Fisher MC. Factors driving pathogenicity vs. prevalence of amphibian panzootic chytridiomycosis in Iberia. Ecol Lett. 2010;13:372-82.

158. James TY, Litvintseva AP, Vilgalys R, Morgan JA, Taylor JW, Fisher MC, Berger L, Weldon C, du Preez L, Longcore JE. Rapid global expansion of the fungal disease chytridiomycosis into declining and healthy amphibian populations. PLoS Pathog. 2009;5:e1000458.

159. Blaustein AR, Wildy EL, Belden LK, Hatch A. Influence of abiotic and biotic factors on amphibians in ephemeral ponds with special reference to longtoed salamanders (Ambystoma macrodacty/um). Isr J Zool. 2001;47:333-45.

160. Gerlanc NM, Kaufman GA. Habitat of origin and changes in water chemistry influence development of western chorus frogs. J Herpetol. 2005;39:254-65.

161. Niehaus AC, Wilson RS, Franklin CE. Short- and long-term consequences of thermal variation in the larval environment of anurans. J Anim Ecol. 2006;75: 686-92.

162. Rogers TN, Chalcraft DR. Pond hydroperiod alters the effect of densitydependent processes on larval anurans. Can J Fish Aquat Sci. 2008;65:2761-8.

163. Brockelman WY. An analysis of density effects and predation in Bufo americanus tadpoles. Ecology. 1969;50:632-44. 
164. Scott DE. Effects of larval density in Ambystoma opacum: an experiment large-scale field enclosures. Ecology. 1990;71:296-306.

165. Scott DE. Effect of larval density on life history traits in Ambystoma opacum. Ecology. 1994;75:1383-96.

166. Semlitsch RD, Caldwell JP. Effects of density on growth, metamorphosis, and survivorship in tadpoles of Scaphiopus holbrooki. Ecology. 1982;63: 905-11.

167. Wilbur HM. Density-dependent aspects of growth and metamorphosis in Bufo americanus. Ecology. 1977;58:196-200.

168. Mitchell T, Alton LA, White CR, Franklin CE. Relations between conspecific density and effects of ultraviolet-b radiation on tadpole size in the striped marsh frog. Conserv Biol. 2012;26:1112-20.

169. Barbosa P, Castellanos I, editors. Ecology of Predator-Prey Interactions. Oxford: Oxford University Press; 2005.

170. Hawlena D, Schmitz OJ. Physiological stress as fundamental mechanism linking predation to ecosystem functioning. Am Nat. 2010;176:537-56.

171. Warkentin KM. Adaptive plasticity in hatching age: a response to predation risk trade-offs. Proc Natl Acad Sci U S A. 1995;92:3507-10.

172. Wilson RS, Kraft PG, Van Damme R. Predator-specific changes in morphology and swimming performance of larval Rana lessonae. Funct Ecol. 2005;19:238-44.

173. Kats LB, Petranka JW, Sih A. Antipredator defenses and the persistence of amphibian larvae with fishes. Ecology. 1988;69:1865-70.

174. Skelly DK. Activity level and susceptibility of anuran larvae to predation. Anim Behav. 1994:47:465-8.

175. Kraft PG, Franklin CE, Blows MW. Predator-induced phenotypic plasticity in tadpoles: extension or innovation. J Evol Biol. 2006;19:450-8.

176. Williamson CE, Zepp RG, Lucas RM, Madronich S, Austin AT, Ballaré CL, Norval M, Sulzberger B, Bais AF, McKenzie RL, Robinson SA, Häder D-P, Paul ND, Bornman JF. Solar ultraviolet radiation in a changing climate. Nat Clim Chang. 2014:4:434-41.

177. van de Mortel TF, Buttemer WA. Are Litoria aurea eggs more sensitive to ultraviolet-B radiation than eggs of sympatric $L$. peronii or $L$. dentata? Am Zool. 1996;30:150-7.

178. Blaustein AR, Edmond B, Kiesecker JM, Beatty JJ, Hokit DG. Ambient ultraviolet radiation causes mortality in salamander eggs. Ecol Appl. 1995;5: 740-3.

179. Anzalone CR, Kats LB, Gordon MS. Effect of solar UV-B radiation on embyronic development in Hyla cadaverina, Hyla regilla, and Taricha torosa. Conserv Biol. 1998:12:646-53.

180. Macías G, Marco A, Blaustein AR. Combined exposure to ambient UVB radiation and nitrite negatively affects survival of amphibian early life stages. Sci Total Environ. 2007;385:55-65.

181. Crump D, Berrill M, Coulson D, Lean D, McGillivray L, Smith A. Sensitivity of amphibian embryos, tadpoles, and larvae to enhanced UV-B radiation in natural pond conditions. Can J Zool. 1999;77:1956-66.

182. Belden LK, Blaustein AR. Population differences in sensitivity to UV-B radiation for larval long-toed salamanders. Ecology. 2002;83:1586-90.

183. Lizana M, Pedraza EM. The effects of UV-B radiaiton on toad mortality in mountainous areas of central Spain. Conserv Biol. 1998;12:703-7.

184. Tietge JE, Diamond SA, Ankley GT, DeFoe DL, Holcombe GW, Jensen KM, Degitz SJ, Elonen GE, Hammer E. Ambient solar UV radiation causes mortality in larvae of three species of Rana under controlled exposure conditions. Photochem Photobiol. 2001;74:261-8.

185. Ankley GT, Diamond SA, Tietge JE, Holcombe GW, Jensen KM, DeFoe DL, Peterson R. Assessment of the risk of solar ultraviolet radiation to amphibians. I. Dose-dependent induction of hindlimb malformations in the northern leopard frog (Rana pipiens). Environ Sci Technol. 2002;36:2853-8.

186. Ankley GT, Tietge JE, Holcombe GW, DeFoe DL, Diamond SA, Jensen KM, Degitz SJ. Effects of laboratory ultraviolet radiation and natural sunlight on survival and development of Rana pipiens. Can J Zool. 2000;78:1092-100.

187. Castañaga LA, Asorey CM, Sandoval MT, Pérez-Coll CS, Argibay TI, Herkovits J. Stage-dependent teratogenic and lethal effects exerted by ultraviolet $B$ radiation on Rhinella (Bufo) arenarum embryos. Environ Toxicol Chem. 2009; 28:427-33.

188. Weyrauch SL, Grubb TC Jr. Effects of the interactions between genetic diversity and UV-B radiation on wood frog fitness. Conserv Biol. 2006;20: $802-10$

189. Smith GR, Waters MA, Rettig JE. Consequences of embryonic UV-B exposure for embryos and tadpoles of the plains leopard frog. Conserv Biol. 2000;14: 1903-7.
190. Pahkala M, Merilä J, Ots I, Laurila A. Effects of ultraviolet-B radiation on metamorphic traits in the common frog Rana temporaria. J Zool. 2003;259: 57-62.

191. Blaustein AR, Kiesecker JM, Chivers DP, Anthony RG. Ambient UV-B radiation causes deformities in amphibian embryos. Proc Natl Acad Sci U S A. 1997; 94:13735-7.

192. Gosner KL. A simplified table for staging anuran embryos and larvae with notes on identification. Herpetologica. 1960;16:183-90.

193. Pahkala M, Laurila A, Merilä J. Effects of ultraviolet-B radiation on common frog Rana temporaria embryos from along a latitudinal gradient. Oecologia. 2002;133:458-65.

194. Worrest RC, Kimeldorf DJ. Distortions in amphibian development induced by ultraviolet-B enhancement (290-315 nm) of a simulated solar spectrum. Photochem Photobiol. 1976;24:377-82.

195. Worrest RC, Kimeldorf DJ. Photoreactivation of potentially lethal, UVinduced damage to boreal toad (Bufo boreas boreas) tadpoles. Life Sci. 1975;17:1545-50

196. Bruggeman DJ, Bantle JA, Goad C. Linking teratogenesis, growth, and DNA photodamage to artificial ultraviolet B radiation in Xenopus laevis larvae. Environ Toxicol Chem. 1998;17:2114-21.

197. Formicki G, Zamachowski W, Stawarz R. Effect of UV-A and UV-B on oxygen consumption in common toad (Bufo bufo) tadpoles. J Zool. 2003;259:317-26.

198. Flamarique IN, Ovaska K, Davis TM. UV-B induced damage to the skin and ocular system of amphibians. Biol Bull. 2000;199:187-8.

199. Fite KV, Blaustein AR, Bengston L, Hewitt HE. Evidence of retinal light damage in Rana cascadae: a declining amphibian species. Copeia. 1998; 1998:906-14.

200. Ankley GT, Tietge JE, DeFoe DL, Jensen KM, Holcombe GW, Durhan EJ, Diamond SA. Effects of ultraviolet light and methoprene on survival and development of Rana pipiens. Environ Toxicol Chem. 1998;17:2530-42.

201. Kats LB, Bucciarelli GM, Schlais DE, Blaustein AR, Han BA. Ultraviolet radiation influences perch selection by a neotropical poison-dart frog. PLoS One. 2012;7:e51364

202. Bernhard G, Mayer B, Seckmeyer G, Moise A. Measurements of spectral solar UV irradiance in tropical Australia. J Geophys Res. 1997;102:8719-30

\section{Submit your next manuscript to BioMed Central and we will help you at every step:}

- We accept pre-submission inquiries

- Our selector tool helps you to find the most relevant journal

- We provide round the clock customer support

- Convenient online submission

- Thorough peer review

- Inclusion in PubMed and all major indexing services

- Maximum visibility for your research

Submit your manuscript at www.biomedcentral.com/submit
Biomed Central 